ENTREPRENEURSHIP AND SUSTAINABILITY ISSUES

ISSN 2345-0282 (online) http://jssidoi.org/jesi/

2021 Volume 8 Number 3 (March)

http://doi.org/10.9770/jesi.2021.8.3(13)

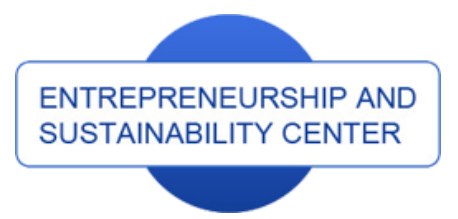

Publisher

http://jssidoi.org/esc/home enterprise

europe

network

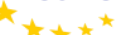

Business Support on Your Doorstep

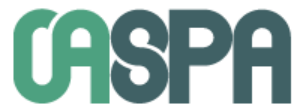

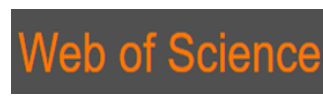

I Clarivate

\title{
THE SUSTAINABLE DEVELOPMENT OF TRANSPORT ENTERPRISES IN THE CONTEXT OF MACROECONOMIC CONDITIONS. THE CASE OF CENTRAL AND EASTERN EUROPEAN COUNTRIES
}

\author{
Michal Comporek ${ }^{1}$, Magdalena Kowalska ${ }^{2}$, Anna Misztal ${ }^{3}$ \\ ${ }^{1,2,3}$ Faculty of Economics and Sociology, University of Lodz, 90-255 Lodz, Poland

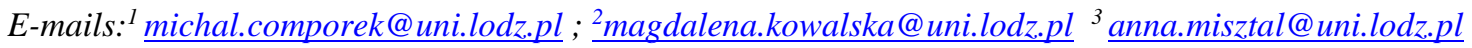

Received 10 November 2020; accepted 15 January 2021; published 30 March 2021

\begin{abstract}
The issue of sustainable development is critical in globalization, the rapid growth of the industry, technological progress, and climate change. Sustainable development is the realization of economic, social, and environmental goals. It requires all actors of socioeconomic life, including enterprises, organizations, institutions, and countries. Sustainable development of an enterprise means improving the financial and property situation while taking care of employees and local communities' health and development and taking action to protect the natural environment. This paper aims to assess the impact of macroeconomic conditions on the sustainable development of transport enterprises in Central and Eastern European Countries (CEECs) in the period from 2008 to 2018. The selection of transport enterprises for the research sample is related to their high impact on economies in the analyzed countries, their significant negative impact on the natural environment. Moreover, transport enterprises play a vital role in the development of other economic sectors. The authors discuss the fundamental theoretical issues related to enterprises' sustainable development and the research result conducted in CEECs. The study results indicate a statistically significant relationship between the indicator of sustainable development and the hand of the macroeconomic condition in all analyzed countries. The highest correlation was observed in Romania, Hungary, and Slovenia, while the lowest in Croatia. The story of socio-economic development in surveyed countries plays a fundamental role in achieving sustainable development of transport enterprises.
\end{abstract}

Keywords: macroeconomic conditions; sustainable development; transport enterprises

Reference to this paper should be made as follows: Comporek, M., Kowalska, M., Misztal, A. 2021. The sustainable development of transport enterprises in the context of macroeconomic conditions. The case of Central and Eastern European countries. Entrepreneurship and Sustainability Issues, 8(3), 226-247. http://doi.org/10.9770/jesi.2021.8.3(13)

JEL Classifications: D22, E10, Q56

Additional disciplines ecology and environment 


\section{ENTREPRENEURSHIP AND SUSTAINABILITY ISSUES}

ISSN 2345-0282 (online) http://jssidoi.org/jesi/

2021 Volume 8 Number 3 (March)

http://doi.org/10.9770/jesi.2021.8.3(13)

\section{Introduction}

The concept of sustainable development of enterprises, based on a triad of economic, social, and environmental objectives - with particular emphasis on a long-term approach to protecting natural resources - seems crucial in all branches of the modern economy. Also, in the case of the transport industry, which is the fastest-growing sector from the perspective of the consumption of energy and the production of greenhouse gases (GHGs) in the European Union, competing enterprises must face the challenge to behave in an environmentally sustainable and socially responsive manner while creating and increasing shareholder's wealth. The sustainable development of transport enterprises depends on several factors, external and internal. External factors include macroeconomic conditions, implemented environmental policy, climate and economic trends, the level of social and ecological awareness, technical and technological infrastructure. The internal states have the enterprise's financial and property situation, environmental awareness, implemented environmental policy.

This paper is theoretical and empirical. The theoretical part describes selected problems of sustainable development of enterprises. The practical piece of this paper contains the results of the research (an econometric model of the influence of macroeconomic conditions on the sustainable development of enterprises, estimated by the Least Square Method). This paper aims to assess the impact of macroeconomic conditions on the sustainable development of transport enterprises in Central and Eastern European Countries (CEECs) in the period from 2008 to 2018 .

The authors focus on a sample of transport enterprises from CEECs, which are also members of the European Union (EU). These countries share a common history, location, and similar level of socio-economic development. Macroeconomic conditions are associated with a political transformation, integration with the EU, and the development of the global economic system.

The selection of transport enterprises for the research sample is related to their high impact on economies in the analyzed countries and significant negative impact on the natural environment. Moreover, transport enterprises play a vital role in the development of other economic sectors.

\section{Sustainable development of enterprise - theoretical background}

The term "sustainable development" comes from the concept of "sustained yield" - the seventeenth doctrine that postulated to hand woodlands undiminished to future generations (Duerr 1975). As noticed Grober (2007), in 1713, Hanns Carl von Carlowitz, head of the Royal Mining Office in the Kingdom of Saxony, introduces the expression "nachhaltig" to meet the challenge of a predicted shortage of timber, the critical resource of the time. Afterward, the concept of sustainable development has evolved considerably, expanding its scope to environmental protection and socio-economic matters.

In 1980, the International Union for the Conservation of Nature, under the UN-General Secretary's patronage, published the declaration entitled "Living Resource Conservation for Sustainable Development." It was the first international document on living resource conservation produced with inputs from governments, nongovernmental organizations, and other experts (IUCN 1980). In 1987 the term "sustainable development" gained prominence in the report "Our Common Future," published by the World Commission on Environment and Development (that is also commonly known as the Brundtland Report). According to the Brundtland Commission, sustainable development "meets the needs of the present without compromising future generations' ability to meet their own needs" (World Commission on Environment and Development 1987). Five years later, modern optics for mentioned issues entered the global stage during the 1992 "Earth Summit" in Rio de Janeiro, with the idea of - among other things - saving "blue planet." Another international organization - OECD - 
identifies this phenomenon as "seeks to balance the economic, environmental, and social dimensions of development in a long-term and global perspective. It implies a broad view of human welfare, long term perspective about the consequences of today's activities, and the full involvement of civil society to reach viable solutions" (OECD 2000).

Over the last quarter of a century, a wide range of theoretical approach to sustainable development has evolved with several meanings (Gatto 1995; Paehlke 2005; Blewitt 2008; Ciegis 2009; Barbosa et al. 2014; Moore 2019) and no consensus on its purpose, undertaken activities and the effects of these activities. The idea of sustainable development is still flexible and open to interpretation (Prugh, Assadourian 2003; Pieloch et al. 2020).

Regardless of whether researchers are more focused on ecological roots or the prism of economic or social issues, sustainable development based on three crucial components: economic growth, social equity for meeting the needs of today's generation, and environmental protection for the ability to meet today's and future generation's needs (Behrends et al. 2008; Pieloch et al. 2020; Verga Matos et al. 2020). Fig. 1 shows the general concept and the principles of a modern view on sustainable development.

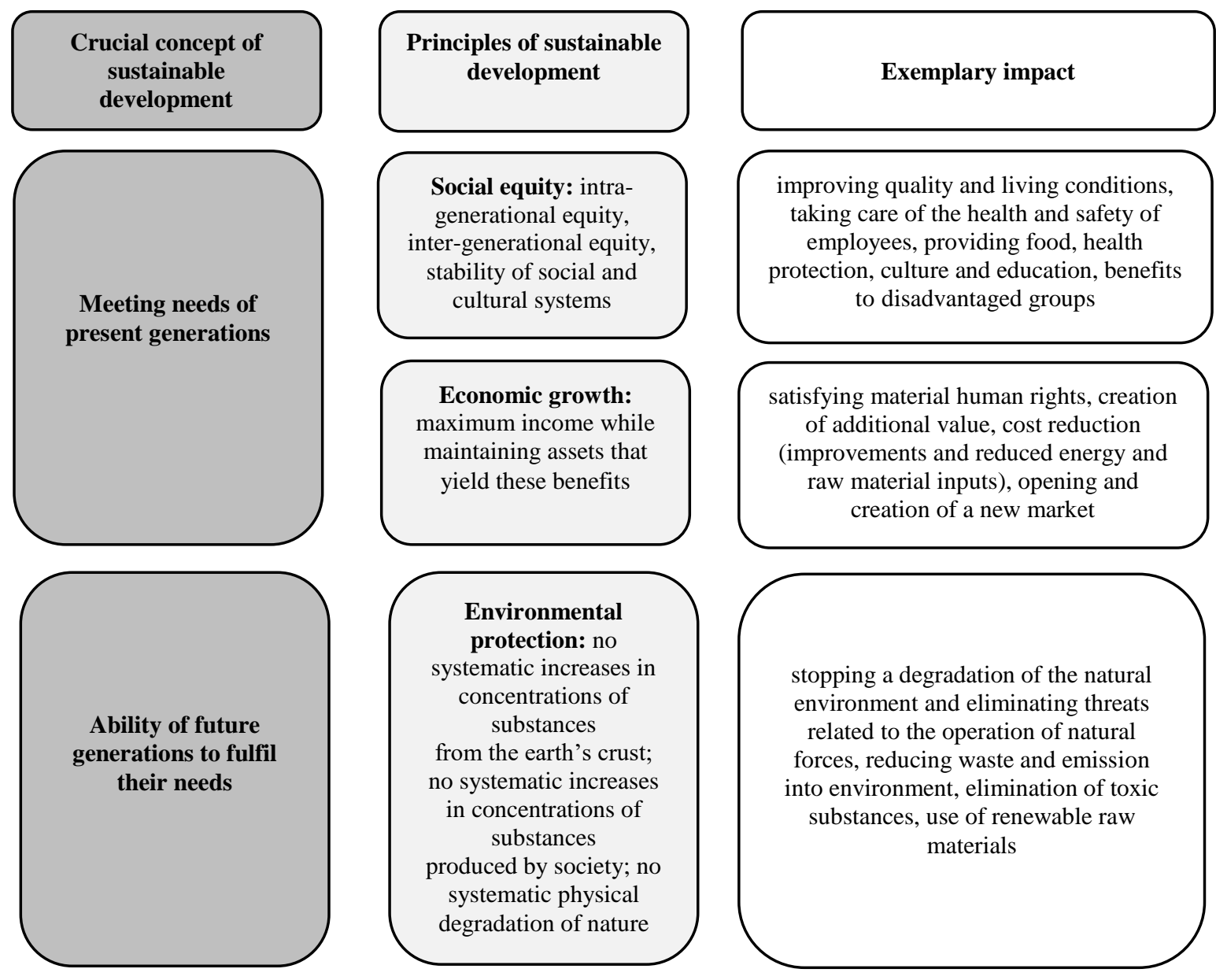

Fig. 1. The general concept and the principles of modern view on sustainable development. Source: own study based on: Behrends et al. (2008); Ciegis, Zeleniute (2008); Gonzalez-Cabezas et al. (2018). 
ENTREPRENEURSHIP AND SUSTAINABILITY ISSUES

ISSN 2345-0282 (online) http://jssidoi.org/jesi/

2021 Volume 8 Number 3 (March)

http://doi.org/10.9770/jesi.2021.8.3(13)

Sustainable development is one of the critical challenges for modern enterprises. As stressed Weidinger (2014), "without sustainable organizations, there is no sustainable development; thus, no future." The forces behind sustainable development influence the strategic playing field for business, including rapid technology development, new economic life in formerly stagnant political systems, or and rampant globalization in many industries (Hedstrom et al. 1998). International Institute for Sustainable Development (1992) takes the view that "if sustainable development is to achieve its potential, it must be integrated into the planning and measurement systems of business enterprises."

Considerations as to whether firms have social or environmental responsibility beyond shareholder wealth maximization have a long history (Joshi, Lee 2016), starting with Bowen (1953), Davis (1960), Friedman (1970). The concept of sustainable development has become an important driving force in how business operations are carried out on capital markets and a determination emphasizing the pro-social sense and nature of an enterprise's activity. Because the direct motive for establishing an economic entity is the desire to meet broadly understood social needs, the managerial staff, striving to achieve a satisfactory level of productivity, profitability, product quality, economic growth, value-added, return on investment, cannot forget about: welfare, respect of human rights, health protection, social security, employee satisfaction and, on the other hand, reduction of emissions and pollution, smart use of resources, biodiversity, security ecosystems, protection of natural resources, recycling, the use of environmentally friendly production (Grudzewski et al. 2010; Grabara et al. 2015; Andryashina, et al. 2020; Abdi et al. 2020).

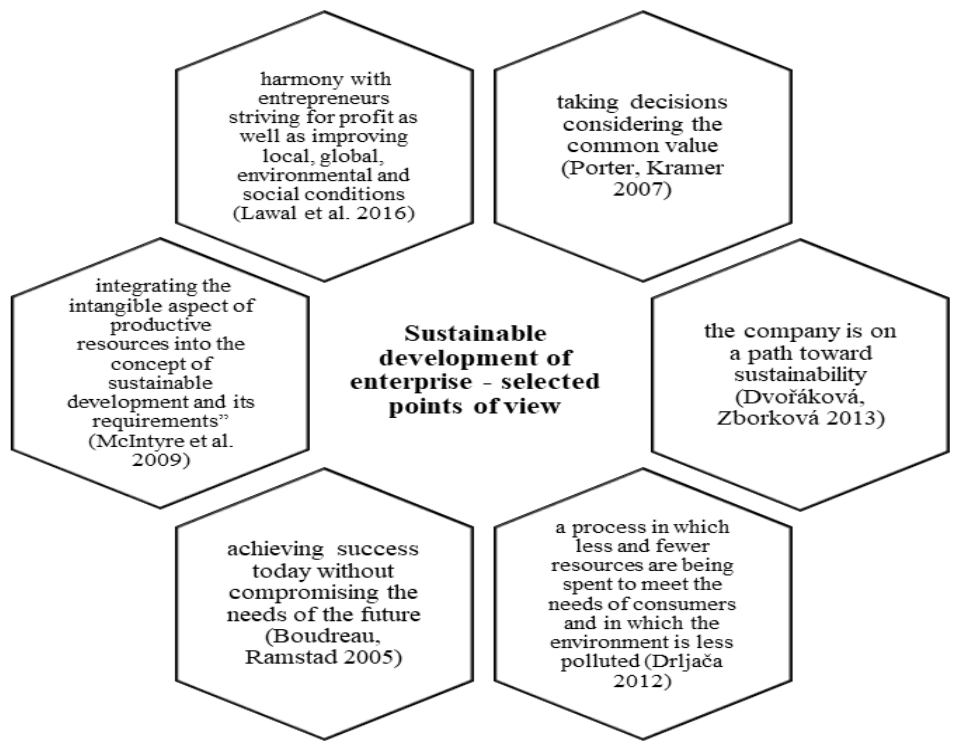

Fig. 2. Selected approaches to enterprise sustainable development defining

Source: own study based on: Porter, Kramer (2007); Dvořáková, Zborková (2013); Drljača (2012); Boudreau, Ramstad (2005); MiIntyre et al. (2009), Lawal et al. (2016).

There is no universally accepted definition of sustainable development of enterprise (Fig. 2). What is more, researchers often link this concept with terms of: "corporate sustainability," "sustainability-driven entrepreneurship," or "sustainable-minded entrepreneurship" (Majid et al. 2012; Gagnon 2012; Del Giudice et al. 2020). According to the International Institute for Sustainable Development, it "means adopting business strategies and activities that meet the needs of the enterprise and its stakeholders today while protecting, sustaining and enhancing the human and natural resources that will be needed in the future." 


\section{ENTREPRENEURSHIP AND SUSTAINABILITY ISSUES}

ISSN 2345-0282 (online) http://jssidoi.org/jesi/

2021 Volume 8 Number 3 (March)

http://doi.org/10.9770/jesi.2021.8.3(13)

Oželienè (2017) defines this category as "a holistic approach of thinking of business which seeks to integrate consideration of the three aspects of sustainability - social, environmental and economical." However, individual researchers incorporate all sustainability dimensions (social, economic, ecological) into the subject matter with different emphasis. Crals and Vereeck (2004) underline that a fundamental principle of sustainable entrepreneurship involves businesses inculcating the consciousness to continually demonstrate ethical behavior and contribute to economic development while simultaneously ushering an era of improvement in the overall well-being of employees, their families, and the society at large. On the contrary, Witkowski (2010) points out that the environmental aspect seems to be the most important, probably because the non-renewable resources are the most substantial barrier to sustainable development.

The sustainable development of enterprises depends on several factors. Research results indicate the importance of external and internal conditions (Misztal, Kowalska 2020). External conditions include the level of socioeconomic development, legal, environmental regulations, membership of countries in international organizations related to environment conservation, financial and institutional support for pro-ecological activities, and ecological awareness. Internal conditions include financial and property situation of enterprises, profitability, financial liquidity, productivity, environmental awareness of the management staff, type of business activity, accumulated human capital, innovation (Lorenc, Sorokina, 2015; Misztal, 2019).

Macroeconomic conditions create opportunities for enterprises and set requirements and restrictions for them. A higher level of macroeconomic development is associated with greater access to knowledge, a better-educated society, and a higher awareness of the negative impact of economic activity on the natural environment. It seems to us that the more economically and socially developed countries are, the more significant pressure on companies to comply with standards in the care of the social environment and social issues.

\section{Sustainable development of transport enterprises - selected problems}

Concerning the more empirical studies focused on sustainable development of enterprises conducting activities in the transport sector, it is noticeable that investigators analyze the mentioned issues from a different context. As evidenced by Gudmundsson (2004), two major approaches to sustainable development in transport can be distinguished: the first one, that deal with sustainability (with concerns only for the future generations), and the second one - which tackle sustainable development (with concerns for both present and future generations). In this paper, special attention has been focused primarily on the results of research from recent years.

Generally, it is worth emphasizing the lack of broader research on macroeconomic conditions of the sustainable development of transport enterprises, such as the country's economic development, macroeconomic stability, the stability of legal regulations, and support for pro-ecological activities, ecological awareness of people. From this perspective, mainly interest seems to be research carried by Mihai et al. (2019), who test holistically whether the transport sector is heading away from or towards sustainability in a panel of 35 countries in the reference period 1994-2014. They add to the literature new insights concerning the relationship between gross domestic product and various aspects of transport sustainability (such as carbon footprint, carbon intensity, or transport safety). Misztal (2019) devotes her research to the statistical analysis of Polish transport companies' sustainable development. The study results made it possible to assess that the sustainable development of transport companies in 2009-2015 takes place, and - what is more - this development is more rapid compared to the average development of the entire enterprise sector.

One of the biggest problems and the most important things is measuring sustainable development because indicators are crucial to understanding the complexity of environmental, economic, and social actions undertaken to achieve development goals (White et al. 2019; Fried 2020; Winter, Stephan 2020). Thus, there are noticeable numerous empirical studies on transport sustainability indicators (Gudmundsson 2004; Litman 2009; Castillo, 


\section{ENTREPRENEURSHIP AND SUSTAINABILITY ISSUES}

ISSN 2345-0282 (online) http://jssidoi.org/jesi/

2021 Volume 8 Number 3 (March)

http://doi.org/10.9770/jesi.2021.8.3(13)

Pitfield 2010; Andersson, Forslund 2018; Kochov et al. 2020; Nazam et al. 2020). Oberhofer and Fürst (2013), using their model based on an extensive literature review, gather evidence that although decision-makers' attitudes have a significant influence on the companies' actual environmental performance, firm size, and sector affiliation show a more significant contribution. Moreover, they prove that attitude and environmental behavior scored slightly lower among transport companies than in other industries. Next year, Oberhofer and Dieplinger (2014) prove that many companies in the transport sector seem to lack environmental measures. They explained it in two ways: firstly, transport companies seldom face direct end-user contact and are lagging with implement and communicate sustainable behavior; secondly - many enterprises realize that sustainable performance is not always a "necessary evil" but can result in an added value in the long run.

Various studies focus their attention on the narrow "sub-areas" of the transport sector. For example, Behrends et al. (2008) present a definition of sustainable urban freight transport and develop a spectrum of measures detailing it, consisting of two levels of indicators: impact ratios that describe how the urban freight transport violates the principles of sustainability and, on the other hand, performance ratios which provide specific different categories determining the characteristics and performance of the urban transport system. Rai et al. (2018) propose a comprehensive indicator approach to manage sustainable urban freight transport from a local authority perspective. The underlined set of factors develop not only the three conventional pillars of sustainable development (which include: social, environmental, and economic considerations) (Arvidson et al., 2013). Eventually, Bask et al. (2018) examine the role of environmental sustainability in transport operations in ShipperLogistics Service Provider. Their findings indicate that globally-operating transport companies are particularly interested in environmental issues, and it is caused partly due to the external pressures and partly because they see the greening of transport as a potential source of competitive advantage. On the other side, on account of the lack of widely accepted methods for measuring the environmental impact of transports, these enterprises cannot easily share the costs and benefits of environmental initiatives between supply chain members nor use such initiatives as marketing arguments to differentiate their offerings.

\section{Methodology of the research}

The research has been conducted on a sample of transport enterprises from Central and Eastern European Countries (data come from Eurostat), which are members of the European Union. Considering this, we focus on the eleven countries, including Bulgaria, Croatia, Czechia, Estonia, Hungary, Latvia, Lithuania, Poland, Romania, the Slovak Republic, and Slovenia. These countries have a similar geographical location, a shared history, and a similar socio-economic development level.

The authors focus on transport enterprises for the research sample due to their immense importance for analyzing countries' enterprise and economic development. Not without significance is the fact that transport companies harm the environment. Moreover, transport enterprises play a vital role in the development of other economic sectors.

The research's main aim is to assess the impact of macroeconomic conditions on the sustainable development of transport enterprises in Central and Eastern European Countries (CEECs) in the period from 2008 to 2018. In connection with this, the hypothesis is formulated as follows:

"Macroeconomic conditions have a statistically significant impact on the sustainable development of

transport enterprises in Central and Eastern Europe in the period from 2008 to 2018".

Assumption:

- macroeconomic condition is one of the critical factors influencing the social and ecological investments of transport enterprises,

- macroeconomic conditions play a vital role in the development of enterprises in developing economies, 


\section{ENTREPRENEURSHIP AND SUSTAINABILITY ISSUES}

ISSN 2345-0282 (online) http://jssidoi.org/jesi/

2021 Volume 8 Number 3 (March)

http://doi.org/10.9770/jesi.2021.8.3(13)

- the analysis discusses the impact of one factor; it should be noted that sustainable development depends on several internal and qualitative variables (this is a fundamental limitation of the study).

We also formulate the sub hypotheses as follows:

$-\mathrm{H}_{1}$ : "The indicator of sustainable development of enterprises $\left(S D_{T E}\right)$ in the Central and Eastern European countries shows the positive dynamics in the period from 2008 to 2018."

Justification for the $\mathrm{H}_{1}$ hypothesis: the positive trend of sustainable development of transport companies is the result of actions and legal regulations in the field of nature protection, increased customer awareness, and the development of new technologies,

$-\mathrm{H}_{2}$ : "The indicator of macroeconomic conditions $\left(M_{i}\right)$ in the Central and Eastern European countries shows the positive dynamics in the period from 2008 to 2018."

Justification for the $\mathrm{H}_{2}$ hypothesis: the improvement in macroeconomic conditions is mainly due to the recovery from the economic slowdown and the global economic upturn,

$-\mathrm{H}_{3:}$ "The highest average value of the indicator of sustainable development of transport enterprises $\left(S D_{T E}\right)$ shows in countries with the highest average value of macroeconomic conditions (Mi)."

Justification for the H3 hypothesis: a higher level of socio-economic development leads to enterprises' faster sustainable development.

To verify our research hypothesis, we use the Pearson correlation coefficient and Ordinary Least Squares (OLS) because it is the most common estimation method for linear models (our model satisfies the OLS assumptions for linear regression). Our research consists of four stages (Fig. 3).

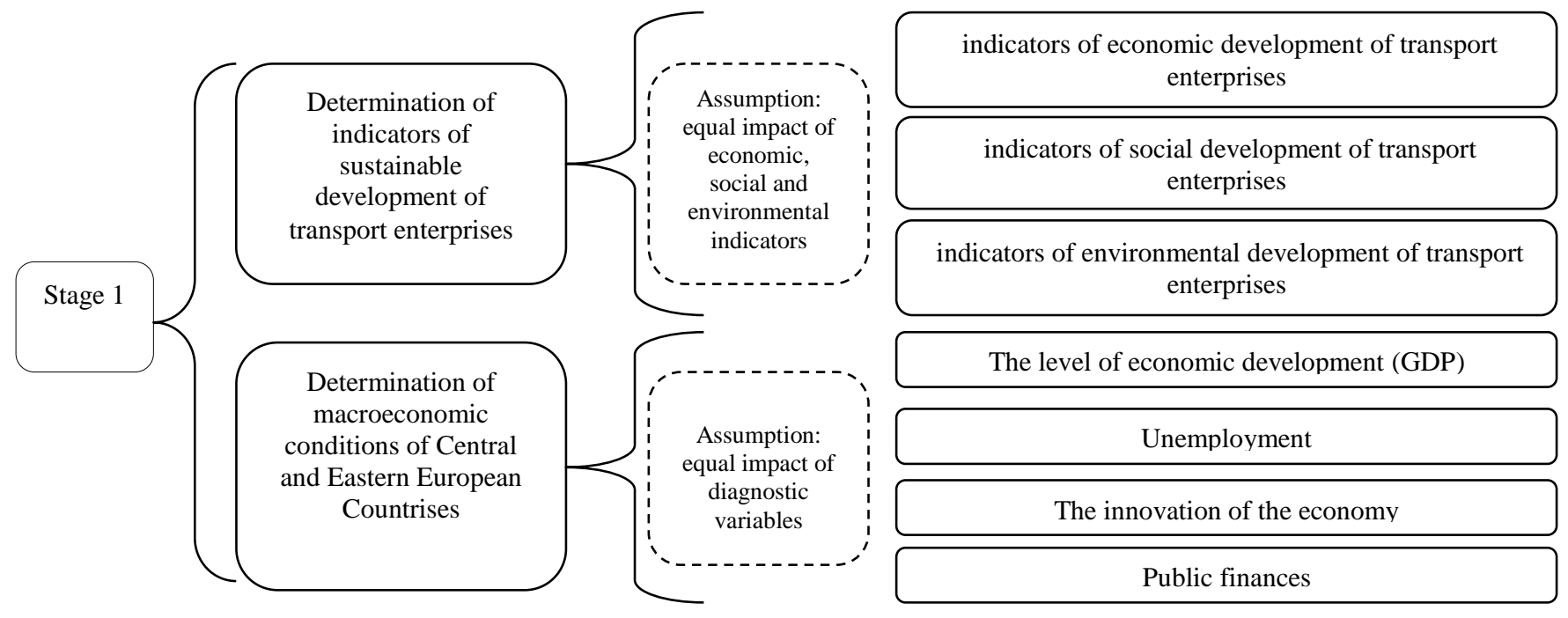

We use the Pearson's correlation to examine the strength and direction of a linear relationship between the
macroeconomic conditions of the studied countries and the sustainable development of transport enterprises.

Fig. 3. Research methodology

Source: own study.

First, we form a indicator of sustainable development of transport enterprises and a indicator of the macroeconomic condition in Central and Eastern European Countries, a sum of standardized sub-indices. We conduct the preliminary analysis of variables in terms of the degree of correlation to eliminate those containing 
repeated information. As the threshold value, we adopt the Pearson correlation coefficient at $|0,75|$ (Dziekański, 2017). The selection of variables base on the literature, as well as results from the data availability.

To calculate the indicators of economic, social, and environmental development of transport enterprises (SDTE), we use 25 explanatory variables, which have met the statistical, substantial, and formal criteria (Table 1). To calculate SDTE, we use the following formula:

$$
\mathrm{SD}_{\mathrm{TE}}=\mathrm{ED}_{\mathrm{TE}}+\mathrm{SOD}_{\mathrm{TE}}+\mathrm{ENVD}_{\mathrm{TE}}=\mathrm{y}_{1}+\ldots+\mathrm{y}_{8}+\mathrm{y}_{9}+\ldots+\mathrm{y}_{18}+\mathrm{y}_{19}+\ldots+\mathrm{y}_{25}
$$

where: $\mathrm{ED}_{\mathrm{TE}}$ is the indicator of economic development of transport enterprises; $\mathrm{SOD}_{\mathrm{TE}}$ means the indicator of social

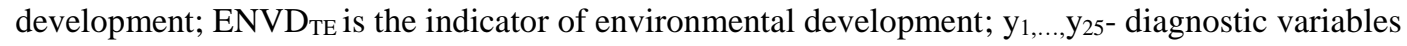

Table 1. Diagnostic variables used in the indicator of sustainable development of transport enterprises (SDTE)

\begin{tabular}{|c|c|c|c|c|}
\hline index & Diagnostic & Description of the variable & Stimulant & Destimulant \\
\hline \multirow{8}{*}{ 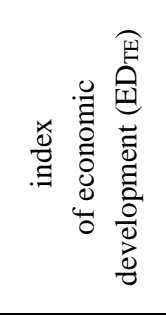 } & $\mathrm{y}_{1}$ & Transport enterprises- number & $\mathrm{x}$ & \\
\hline & $\mathrm{y} 2$ & Turnover or gross premiums [million euro] & $\mathrm{x}$ & \\
\hline & $\mathrm{y}_{3}$ & Production value [million euro] & $\mathrm{x}$ & \\
\hline & $\mathrm{y}_{4}$ & Value added at factor cost [million euro] & $\mathrm{x}$ & \\
\hline & $\mathrm{y}_{5}$ & Gross operating surplus [million euro] & $\mathrm{x}$ & \\
\hline & $\mathrm{y} 6$ & Total purchases of goods and services [million euro] & $\mathrm{x}$ & \\
\hline & $\mathrm{y} 7$ & Gross investment in tangible goods [million euro] & $\mathrm{x}$ & \\
\hline & $\mathrm{y}_{8}$ & Investment rate (investment/value added at factors cost) [\%] & $\mathrm{x}$ & \\
\hline \multirow{10}{*}{ 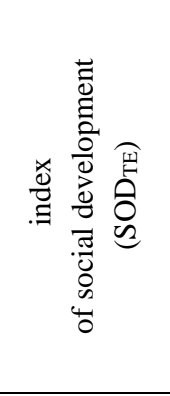 } & y9 & Personnel costs - million euro & & $\mathrm{x}$ \\
\hline & $\mathrm{y}_{10}$ & Wages and Salaries [million euro] & $\mathrm{x}$ & \\
\hline & $\mathrm{y}_{11}$ & Social security costs [million euro] & $\mathrm{x}$ & \\
\hline & $\mathrm{y}_{12}$ & Employee- number & $\mathrm{x}$ & \\
\hline & $\mathrm{y}_{13}$ & Turnover per person employed [thousand euro] & $\mathrm{x}$ & \\
\hline & $\mathrm{y} 14$ & Apparent labour productivity [thousand euro] & $\mathrm{x}$ & \\
\hline & $\mathrm{y} 15$ & Gross value added per employee [thousand euro] & $\mathrm{x}$ & \\
\hline & $\mathrm{y} 16$ & Share of personnel costs in production - percentage & & $\mathrm{x}$ \\
\hline & $\mathrm{y}_{17}$ & Growth rate of employment [\%] & $\mathrm{x}$ & \\
\hline & $\mathrm{y} 18$ & Investment per person employed [thousands euro] & $\mathrm{x}$ & \\
\hline \multirow{7}{*}{ 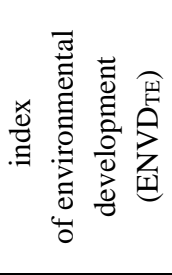 } & $\mathrm{y} 19$ & Carbon dioxide emission [tons] & & $\mathrm{x}$ \\
\hline & $\mathrm{y} 20$ & Methane emission [tons] & & $\mathrm{x}$ \\
\hline & $\mathrm{y}_{21}$ & Nitrous oxide emission [tons] & & $\mathrm{x}$ \\
\hline & $\mathrm{y}_{22}$ & Sulphur oxides emission [tons] & & $\mathrm{x}$ \\
\hline & $\mathrm{y}_{23}$ & Carbon monoxide emission [tons] & & $\mathrm{x}$ \\
\hline & $\mathrm{y} 24$ & Nitrogen oxides emission [tons] & & $\mathrm{x}$ \\
\hline & $\mathrm{y}_{25}$ & Amonia emissions [tons] & & $\mathrm{x}$ \\
\hline
\end{tabular}

Source: own study based on Eurostat [https://ec.europa.eu/Eurostat], access: 02.05.2020.

To calculate the indicators of macroeconomic conditions (Mi) in the Central and Eastern European Countries we use the following formula with 12 explanatory variables:

where $\mathrm{x}_{1, \ldots}, \mathrm{x}_{12}$ are diagnostic variables.

$$
\mathrm{Mi}=\mathrm{x}_{1}+\ldots+\mathrm{x}_{12}
$$

We want to create a simple and transparent measure that refers to such key areas as the level of economic development, the level of unemployment, the innovation of the economy, and public finances (Table 2). 
Table 2. Diagnostic variables used in the indicator of macroeconomics condition $\left(\mathrm{M}_{\mathrm{i}}\right)$ in the Central and Eastern European Countries

\begin{tabular}{|c|c|c|c|c|}
\hline index & Diagnostic & Description of the variable & Stimulant & Destimulant \\
\hline \multirow{12}{*}{ 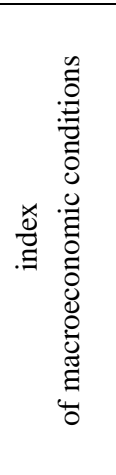 } & $\mathrm{X}_{1}$ & GDP [million euro] & $\mathrm{x}$ & \\
\hline & $\mathrm{x}_{2}$ & Production [\%] & $\mathrm{x}$ & \\
\hline & $\mathrm{x}_{3}$ & Unemployment rate [\%] & & $\mathrm{x}$ \\
\hline & $\mathrm{X} 4$ & $\mathrm{HICP}[\%]$ & & $\mathrm{x}$ \\
\hline & $\mathrm{X} 5$ & Government deficit/surplus & & $\mathrm{x}$ \\
\hline & $\mathrm{X}_{6}$ & Current account balance percentage of GDP & $\mathrm{x}$ & \\
\hline & $\mathrm{X} 7$ & Labour productivity and unit labour costs & $\mathrm{x}$ & \\
\hline & $\mathrm{X} 8$ & Final consumption expenditure of households and non-profit & $\mathrm{x}$ & \\
\hline & $\mathrm{x} 9$ & Exports of goods and services & $\mathrm{x}$ & \\
\hline & $\mathrm{X}_{10}$ & Imports of goods and services & & $\mathrm{x}$ \\
\hline & $\mathrm{X}_{11}$ & External balance of goods and services & $\mathrm{x}$ & \\
\hline & $\mathrm{X} 12$ & R\&D expenditure & $\mathrm{x}$ & \\
\hline
\end{tabular}

Source: own study based on Eurostat [https://ec.europa.eu/Eurostat], access: 02.05.2020.

Then, we transform the explanatory variables to unify their measuring scales using the following formulas (Szanduła 2014):

— for the stimulants:

— for the enterprise sustainable development indicator:

$$
z_{i j}=\frac{y_{i j}-\min _{i}\left[y_{i j}\right\}}{\max _{i}\left[y_{i j}\right]-\min _{i}\left[y_{i j}\right]}, z_{i j} \in[0 ; 1]
$$

— for the macroeconomic indicator:

$$
z_{i j}=\frac{x_{i j}-\min _{i}\left[x_{i j}\right\}}{\max \left\{x_{i j}\right]-\min _{i}\left[x_{i j}\right]}, z_{i j} \in[0 ; 1]
$$

- for the destimulants:

— for the enterprise sustainable development indicator:

$$
z_{i j}=\frac{\max _{i}\left[y_{i j}\right]-y_{i j}}{\max _{i}\left[y_{i j}\right]-\min _{i}\left[y_{i j}\right]}, z_{i j} \in[0 ; 1] .
$$

— for the macroeconomic indicator:

$$
z_{i j}=\frac{\max _{i}\left[x_{i j}\right]-x_{i j}}{\max _{i}\left[x_{i j}\right]-\min _{i}\left[x_{i j}\right]}, z_{i j} \in[0 ; 1] .
$$

where: $z_{i j}$ stands for the normalized value of the $j$-th variable in the $i$-th year; $x_{i j}$ is the value of the $j$-th variable in the $i$ thyear; $\min _{i}\left\{x_{i j}\right\} / \min _{i}\left\{y_{i j}\right\}$ is the lowest value of the $j$-th variable in the $i$-th year; $\max _{i}\left\{x_{i j}\right\} / \max _{i}\left\{y_{i j}\right\}$ is the highest value of the $j$-th variable in the $i$-th year.

To calculate the indicator of sustainable development of transport enterprises $\left(\mathrm{SD}_{\mathrm{TE}}\right)$, as well as its sub-indices $\left(\mathrm{ED}_{\mathrm{TE}}, \mathrm{SOD}_{\mathrm{TE}}\right.$, and $\mathrm{ENVD}_{\mathrm{TE}}$ ), and the macroeconomic condition indicator (Mi) we assume the same impact of different indices on the aggregate measure. We use the following formula:

$$
\mathrm{SI}_{\mathrm{i}}=\frac{1}{\mathrm{n}} \sum_{\mathrm{j}=1}^{\mathrm{n}} \mathrm{z}_{\mathrm{ij}},(\mathrm{i}=1,2, \ldots, \mathrm{n})
$$

where: $S I_{i}$ stands for the indicator in the $i$-year; $n$ is the number of metrics; others as above. 
In the next step, we examine the strength and direction of a linear relationship between the macroeconomic conditions of the studied countries $\left(M_{i}\right)$ and the sustainable development of transport enterprises ( $\mathrm{SD}_{\mathrm{TE}}$ ). To do this, we use the Pearson's correlation coefficient given by the formula (Ahlgren et al. 2003; Asuero et al. 2006; Engle 2009):

$$
r_{x y}=\frac{\sum_{i=1}^{n}\left(x_{i}-\bar{x}\right)\left(y_{i}-\bar{y}\right)}{\sqrt{\sum_{i=1}^{n}\left(x_{i}-\bar{x}\right)^{2}} \sqrt{\sum_{i=1}^{n}\left(y_{i}-\bar{y}\right)^{2}}}, \quad r_{x y} \in[-1 ; 1]
$$

where: $r_{x y}$ stands for the Pearson's correlation coefficient; $n$ is the sample size; $x_{i}, y_{i}$ are the individual sample points indexed with $i ; \bar{x}, \bar{y}$ are the sample means. In order to provide details concerning the correct interpretation of correlation results, we adopt the ranges of correlation strength that were suggested by Evans (1996): $\left|r_{x y}\right|=0$ - no correlation; $0<\left|r_{x y}\right| \leq 0.19$ - very weak; $0.20 \leq\left|r_{x y}\right| \leq 0.39$ - weak; $0.40 \leq\left|r_{x y}\right| \leq 0.59$ - moderate; $0.60 \leq\left|r_{x y}\right| \leq 0.79$ - strong; $0.80 \leq\left|r_{x y}\right| \leq 1.00$ - very strong.

Moreover, we adopt statistical significance at 0.05 .

Fourth, in order to assess the links between the sustainable development of enterprises and macroeconomic stabilization, we apply a regression analysis. The simple linear regression of $\mathrm{y}$ on $\mathrm{x}$ is given by the following formula (Freund et al. 2006; Yan, Su 2009; Schmidheiny 2019):

$$
y_{i}=\alpha_{0}+\alpha_{1} x_{i}+\varepsilon_{i}
$$

where: $y_{i}$ is an dependent variable; $x_{i}$ is an independent variable; $\alpha_{0}$ is the intercept, $\alpha_{l}$ is the slope; $\varepsilon_{i}$ denotes the $i$-th residual; $I$ is an observation index.

The estimated model is given by the equation:

$$
y_{i}=\hat{\alpha}_{0}+\hat{\alpha}_{1} x_{i}+e_{i}=\hat{y}_{i}+e_{i}
$$

so the residual for each observation is as follows:

$$
e_{i}=y_{i}-\hat{y}_{i}=y_{i}-\left(\hat{\alpha}_{0}+\hat{\alpha}_{1} x_{i}\right)
$$

For regression analysis, we use the most common estimation method for linear models called the ordinary least squares (OLS) regression. The OLS procedure minimizes the sum of squared residuals (Raykov, Marcoulides 2013):

$$
s\left(\hat{\alpha}_{0}, \hat{\alpha}_{1}\right)=\sum_{i=1}^{n} e_{i}^{2}=\sum_{i=1}^{n}\left(y_{i}-\hat{y}_{i}\right)^{2}=\sum_{i=1}^{n}\left(y_{i}-\hat{\alpha}_{0}-\hat{\alpha}_{1} x_{i}\right)^{2} \rightarrow \min
$$

Solving the minimization problem results in the following expressions (Freund et al. 2006; Yan, Su 2009):

$$
\begin{gathered}
\hat{\alpha}_{1}=\frac{\sum_{i=1}^{n}\left(x_{i}-\bar{x}\right)\left(y_{i}-\bar{y}\right)}{\sum_{i=1}^{n}\left(x_{i}-\bar{x}\right)^{2}}=\frac{\sum_{i=1}^{n}\left(x_{i} y_{i}-n \bar{x} \bar{y}\right)}{\sum_{i=1}^{n} x_{i}^{2}-n \bar{x}^{2}} \\
\hat{\alpha}_{0}=\bar{y}-\hat{\alpha}_{1} \bar{x}
\end{gathered}
$$




\section{ENTREPRENEURSHIP AND SUSTAINABILITY ISSUES}

ISSN 2345-0282 (online) http://jssidoi.org/jesi/

2021 Volume 8 Number 3 (March)

http://doi.org/10.9770/jesi.2021.8.3(13)

Like many statistical analyses, the OLS regression has underlying assumptions (Wilcox 2009), i.e.: a) the regression model is linear in the coefficients and the error term; b) the error term has a population mean of zero; c) all independent variables are uncorrelated with the error term; d) the observations of the error term are uncorrelated with each other; e) the error term has a constant variance (no heteroscedasticity); f) no independent variable is a perfect linear function of other explanatory variables; g) the error term is normally distributed (this assumption is optional). Our regression model satisfies the above assumptions. The calculation is carried out using GRETL, Statistica and Excel.

\section{The result of research}

The research has been conducted on transport enterprises operating in Central and Eastern European Countries (CEECs) in 2008-2018. The highest average share is in Poland (44\%). From 2008 to 2018, the number of transport enterprises in the CEECs increased by 55015 (Table 3).

Table 3. Research sample

\begin{tabular}{|c|c|c|c|c|c|c|c|c|c|c|c|}
\hline \multirow{2}{*}{ Country } & \multicolumn{11}{|c|}{ Number of transport enterprises } \\
\hline & 2008 & 2009 & 2010 & 2011 & 2012 & 2013 & 2014 & 2015 & 2016 & 2017 & 2018 \\
\hline Bulgaria & 16965 & 19306 & 19084 & 19062 & 19003 & 19461 & 20304 & 21223 & 22711 & 23191 & 23583 \\
\hline Croatia & 10964 & 11706 & 10853 & 9815 & 9208 & 8839 & 8642 & 8562 & 8372 & 8606 & 8969 \\
\hline Czechia & 39345 & 39548 & 39341 & 41153 & 40064 & 38944 & 38610 & 38159 & 38439 & 39791 & 39821 \\
\hline Estonia & 3861 & 3873 & 4027 & 4232 & 4479 & 4761 & 4842 & 5052 & 5244 & 5591 & 5856 \\
\hline Hungary & 32788 & 31382 & 30731 & 30254 & 28578 & 26730 & 26137 & 27039 & 27668 & 28448 & 28652 \\
\hline Latvia & 5387 & 5445 & 5570 & 5426 & 6303 & 6560 & 6951 & 7307 & 7654 & 7498 & 7965 \\
\hline Lithuania & 7264 & 7048 & 6792 & 7331 & 9843 & 10776 & 11596 & 12314 & 13603 & 16118 & 16365 \\
\hline Poland & 148756 & 131974 & 138649 & 145939 & 141739 & 135210 & 140736 & 145993 & 153586 & 155910 & 156982 \\
\hline Romania & 34489 & 35064 & 32774 & 31713 & 34064 & 36127 & 39666 & 41746 & 44504 & 48382 & 48565 \\
\hline Slovakia & 2373 & 553 & 14290 & 16783 & 16734 & 16389 & 16578 & 18039 & 19020 & 20778 & 20801 \\
\hline Slovenia & 8941 & 8807 & 8688 & 8510 & 8491 & 8432 & 8313 & 8445 & 8574 & 8578 & 8589 \\
\hline Total & 311133 & 294706 & 310799 & 320218 & 318506 & 312229 & 322375 & 333879 & 349375 & 362891 & 366148 \\
\hline
\end{tabular}

Source: own study based onEurostat [https://ec.europa.eu/Eurostat], access: 05.04.2020.

In the CEECs, the average value of the indicator of economic development of transport enterprises is in the range of 0.38-0.64, the indicator of social development of transport enterprises is in the range of $0.42-0.60$, and the indicator of environmental development of transport enterprises is in the range of 0.54-0.64. The maximum value of the indicator of the economic development of transport enterprises (EDTE) in the CEECs is observed in Latvia (2017, 2018: 0.89), while the minimum value in Lithuania (2009: 0.03). The maximum value of the indicator of social development of transport enterprises (SODTE) in the CEECs is in Poland (2018: 0.83) and Romania (2018: 0.83); the minimum value also in Poland (2009: 0.11). The maximum value of the indicator of the environmental development of transport enterprises (ENVDTE) in the CEECs is observed in Poland (2014: 0.95), while the minimum value in Czechia (2008: 0.03) (Table 4). 
ENTREPRENEURSHIP AND SUSTAINABILITY ISSUES

ISSN 2345-0282 (online) http://jssidoi.org/jesi/

2021 Volume 8 Number 3 (March)

http://doi.org/10.9770/jesi.2021.8.3(13)

Table 4. indicators of economic, social, environmental and sustainable development of transport enterprises in the Central and Eastern European Countries (in the period from 2008 to 2018)

\begin{tabular}{|c|c|c|c|c|c|c|c|c|c|c|c|c|c|c|c|c|c|}
\hline \multirow{2}{*}{ Country } & \multirow{2}{*}{ indicator } & \multicolumn{11}{|c|}{ Year } & \multicolumn{5}{|c|}{ Descriptive statistics } \\
\hline & & 2008 & 2009 & 2010 & 2011 & 2012 & 2013 & 2014 & 2015 & 2016 & 2017 & 2018 & Median & Mean & Min & Max & SD \\
\hline \multirow{4}{*}{ Bulgaria } & EDTE & 0.24 & 0.07 & 0.18 & 0.28 & 0.27 & 0.40 & 0.66 & 0.70 & 0.74 & 0.79 & \begin{tabular}{|l|}
0.79 \\
\end{tabular} & 0.40 & 0.46 & 0.07 & \begin{tabular}{|l|}
0.79 \\
\end{tabular} & 0.26 \\
\hline & SOD $_{\mathrm{TE}}$ & 0.40 & 0.23 & 0.22 & 0.35 & 0.32 & 0.43 & 0.56 & 0.66 & 0.73 & 0.77 & 0.77 & 0.43 & 0.49 & 0.22 & 0.77 & 0.20 \\
\hline & ENVDTE $_{\text {TE }}$ & 0.61 & 0.51 & 0.80 & 0.81 & 0.60 & 0.78 & 0.68 & 0.52 & 0.43 & 0.47 & 0.47 & 0.60 & 0.61 & 0.43 & 0.81 & 0.14 \\
\hline & SD & 0.42 & 0.27 & 0.40 & 0.48 & 0.40 & 0.54 & 0.63 & 0.62 & 0.63 & 0.68 & 0.68 & 0.54 & 0.52 & 0.27 & 0.68 & 0.13 \\
\hline \multirow{4}{*}{ Croatia } & ED $_{\text {TE }}$ & 0.36 & 0.33 & 0.32 & 0.15 & 0.05 & 0.13 & 0.44 & 0.72 & 0.49 & 0.61 & 0.61 & 0.36 & 0.38 & 0.05 & 0.72 & 0.21 \\
\hline & SODTE & 0.51 & 0.26 & 0.27 & 0.26 & 0.21 & 0.24 & 0.55 & 0.65 & 0.52 & 0.58 & 0.58 & 0.51 & 0.42 & 0.21 & 0.65 & 0.16 \\
\hline & ENVDTE & 0.30 & 0.17 & 0.47 & 0.62 & 0.77 & 0.51 & 0.79 & 0.83 & 0.71 & 0.56 & 0.56 & 0.56 & 0.57 & 0.17 & 0.83 & 0.20 \\
\hline & $\mathbf{S D}_{\mathrm{TE}}$ & 0.39 & 0.25 & 0.36 & 0.34 & 0.34 & 0.29 & 0.59 & 0.73 & 0.57 & 0.58 & 0.58 & 0.39 & 0.46 & 0.25 & 0.73 & 0.15 \\
\hline \multirow{4}{*}{ Czechia } & ED $_{\text {TE }}$ & 0.70 & 0.11 & 0.34 & 0.72 & 0.53 & 0.47 & 0.36 & 0.52 & 0.53 & 0.70 & 0.70 & 0.53 & 0.52 & 0.11 & 0.72 & 0.18 \\
\hline & SOD $_{\mathrm{TE}}$ & 0.53 & 0.22 & 0.23 & 0.52 & 0.44 & 0.45 & 0.39 & 0.57 & 0.60 & 0.72 & 0.72 & 0.52 & 0.49 & 0.22 & 0.72 & 0.16 \\
\hline & ENVDTE $_{\text {TE }}$ & 0.03 & 0.45 & 0.59 & 0.65 & 0.76 & 0.85 & 0.83 & 0.83 & 0.72 & 0.69 & 0.69 & 0.69 & 0.64 & 0.03 & 0.85 & 0.22 \\
\hline & DTE & 0.42 & 0.26 & 0.39 & 0.63 & 0.58 & 0.59 & 0.53 & 0.64 & 0.62 & 0.70 & 0.70 & 0.59 & 0.55 & 0.26 & 0.70 & 0.13 \\
\hline \multirow{4}{*}{ Estonia } & TTE & 0.31 & 0.07 & 0.24 & 0.58 & 0.75 & 0.77 & 0.54 & 0.47 & 0.53 & 0.79 & 0.79 & 0.54 & 0.53 & 0.07 & 0.79 & 0.23 \\
\hline & SOD $_{\mathrm{TE}}$ & 0.38 & 0.18 & 0.30 & 0.52 & 0.65 & 0.66 & 0.59 & 0.55 & 0.56 & 0.80 & 0.80 & 0.56 & 0.55 & 0.18 & 0.80 & 0.19 \\
\hline & ENVD $_{\text {TE }}$ & 0.30 & 0.55 & 0.16 & 0.66 & 0.52 & 0.51 & 0.74 & 0.93 & 0.63 & 0.87 & 0.87 & 0.63 & 0.61 & 0.16 & 0.93 & 0.23 \\
\hline & $\mathrm{SD}_{\mathrm{TE}}$ & 0.33 & 0.26 & 0.23 & 0.59 & 0.64 & 0.65 & 0.62 & 0.65 & 0.57 & 0.82 & 0.82 & 0.62 & 0.56 & 0.23 & 0.82 & 0.19 \\
\hline \multirow{4}{*}{ Hungary } & $\mathbf{E D}_{\mathrm{TE}}$ & 0.42 & 0.25 & 0.25 & 0.34 & 0.26 & 0.39 & 0.59 & 0.73 & 0.64 & 0.88 & 0.88 & 0.42 & 0.51 & 0.25 & 0.88 & 0.23 \\
\hline & SOD $_{\mathrm{TE}}$ & 0.39 & 0.20 & 0.24 & 0.37 & 0.32 & 0.44 & 0.63 & 0.71 & 0.69 & 0.76 & 0.76 & 0.44 & 0.50 & 0.20 & 0.76 & 0.20 \\
\hline & ENVDTE & 0.04 & 0.23 & 0.48 & 0.55 & 0.88 & 0.78 & 0.59 & 0.53 & 0.64 & 0.62 & 0.62 & 0.59 & 0.54 & 0.04 & 0.88 & 0.22 \\
\hline & $\mathrm{SD}_{\mathrm{TE}}$ & 0.28 & 0.23 & 0.32 & 0.42 & 0.49 & 0.53 & 0.61 & 0.66 & 0.66 & 0.75 & 0.75 & 0.53 & 0.52 & 0.23 & 0.75 & 0.18 \\
\hline \multirow{4}{*}{ Latvia } & EDTE & 0.54 & 0.06 & 0.09 & 0.42 & 0.85 & 0.84 & 0.83 & 0.89 & 0.71 & 0.89 & 0.89 & 0.83 & 0.64 & 0.06 & 0.89 & 0.30 \\
\hline & SOD $_{\mathrm{TE}}$ & 0.59 & 0.21 & 0.19 & 0.47 & 0.76 & 0.71 & 0.72 & 0.72 & 0.65 & 0.77 & 0.77 & 0.71 & 0.60 & 0.19 & 0.77 & 0.20 \\
\hline & ENVD $_{\text {TE }}$ & 0.15 & 0.68 & 0.36 & 0.45 & 0.58 & 0.62 & 0.52 & 0.54 & 0.76 & 0.67 & 0.67 & 0.58 & 0.54 & 0.15 & 0.76 & 0.17 \\
\hline & $\mathrm{SD}_{\text {TE }}$ & 0.43 & 0.32 & 0.22 & 0.45 & 0.73 & 0.72 & 0.69 & 0.72 & 0.71 & 0.78 & $\begin{array}{ll}0.78 \\
\end{array}$ & 0.71 & 0.59 & 0.22 & 0.78 & 0.19 \\
\hline \multirow{4}{*}{ Lithuania } & ED $_{\mathrm{TE}}$ & 0.30 & 0.03 & 0.15 & 0.41 & 0.51 & 0.64 & 0.62 & 0.62 & 0.68 & 0.86 & 0.86 & 0.62 & 0.51 & 0.03 & 0.86 & 0.26 \\
\hline & SODTE & 0.37 & 0.13 & 0.25 & 0.50 & 0.52 & 0.59 & 0.61 & 0.61 & 0.70 & 0.82 & 0.82 & 0.59 & 0.54 & 0.13 & 0.82 & 0.21 \\
\hline & ENVD $_{\mathrm{TE}}$ & 0.47 & 0.86 & 0.79 & 0.74 & 0.74 & 0.72 & 0.43 & 0.49 & 0.31 & 0.16 & 0.16 & 0.49 & 0.54 & 0.16 & 0.86 & 0.24 \\
\hline & $\mathrm{SD}_{\mathrm{TE}}$ & 0.38 & 0.33 & 0.40 & 0.55 & 0.59 & 0.65 & 0.55 & 0.57 & 0.56 & 0.62 & 0.62 & 0.56 & 0.53 & 0.33 & 0.65 & 0.10 \\
\hline \multirow{4}{*}{ Poland } & $\mathbf{E D}_{\mathrm{TE}}$ & 0.43 & 0.01 & 0.21 & 0.44 & 0.41 & 0.44 & 0.63 & 0.75 & 0.66 & 0.86 & 0.86 & 0.44 & 0.52 & 0.01 & 0.86 & 0.25 \\
\hline & SOD & 0.43 & 0.11 & 0.38 & 0.49 & 0.49 & 0.46 & 0.62 & 0.70 & 0.67 & 0.83 & 0.83 & 0.49 & 0.55 & 0.11 & 0.83 & 0.20 \\
\hline & ENVD $_{\mathrm{TE}}$ & 0.51 & 0.68 & 0.44 & 0.61 & 0.74 & 0.87 & 0.95 & 0.86 & 0.61 & 0.23 & 0.23 & 0.61 & 0.61 & 0.23 & 0.95 & 0.23 \\
\hline & SDTE & 0.45 & 0.27 & 0.34 & 0.51 & 0.55 & 0.59 & 0.73 & 0.77 & 0.65 & 0.64 & 0.64 & 0.59 & 0.56 & 0.27 & 0.77 & 0.15 \\
\hline \multirow{4}{*}{ Romania } & EDTE & 0.42 & 0.17 & 0.15 & 0.36 & 0.37 & 0.38 & 0.52 & 0.66 & 0.69 & 0.88 & 0.88 & 0.42 & 0.50 & 0.15 & 0.88 & 0.24 \\
\hline & SODTE & 0.49 & 0.21 & 0.25 & 0.45 & 0.41 & 0.43 & 0.50 & 0.58 & 0.67 & 0.83 & 0.83 & 0.49 & 0.51 & 0.21 & 0.83 & 0.19 \\
\hline & ENVD $_{\text {TE }}$ & 0.33 & 0.86 & 0.69 & 0.59 & 0.71 & 0.62 & 0.69 & 0.55 & 0.36 & 0.29 & 0.29 & 0.59 & 0.54 & 0.29 & 0.86 & 0.19 \\
\hline & $\mathrm{SD}_{\mathrm{TE}}$ & 0.41 & 0.41 & 0.36 & 0.47 & 0.49 & 0.48 & 0.57 & 0.60 & 0.57 & 0.67 & 0.67 & 0.49 & 0.52 & 0.36 & 0.67 & 0.10 \\
\hline \multirow{4}{*}{ Slovakia } & ED $_{\mathrm{TE}}$ & 0.18 & 0.10 & 0.36 & 0.54 & 0.61 & 0.77 & 0.68 & 0.70 & 0.62 & 0.69 & 0.69 & 0.62 & 0.54 & 0.10 & 0.77 & 0.21 \\
\hline & SODTE & 0.26 & 0.17 & 0.42 & 0.57 & 0.55 & 0.63 & 0.48 & 0.58 & 0.46 & 0.58 & 0.58 & 0.55 & 0.48 & 0.17 & 0.63 & 0.14 \\
\hline & ENVDTE & 0.21 & 0.44 & 0.51 & 0.61 & 0.79 & 0.73 & 0.83 & 0.67 & 0.57 & 0.59 & 0.59 & 0.59 & 0.59 & 0.21 & 0.83 & 0.17 \\
\hline & $\mathbf{S D}_{\mathrm{TE}}$ & 0.22 & 0.24 & 0.43 & 0.57 & 0.65 & 0.71 & 0.66 & 0.65 & 0.55 & 0.62 & 0.62 & 0.62 & 0.54 & 0.22 & 0.71 & 0.16 \\
\hline \multirow{4}{*}{ Slovenia } & $\mathbf{E D}_{\mathrm{TE}}$ & 0.56 & 0.22 & 0.32 & 0.31 & 0.27 & 0.29 & 0.32 & 0.41 & 0.55 & 0.73 & 0.73 & 0.32 & 0.43 & 0.22 & 0.73 & 0.17 \\
\hline & SOD $_{\mathrm{TE}}$ & 0.57 & 0.47 & 0.52 & 0.38 & 0.36 & 0.37 & 0.41 & 0.47 & 0.57 & 0.66 & 0.66 & 0.47 & 0.49 & 0.36 & 0.66 & 0.11 \\
\hline & ENVD $_{\mathrm{TE}}$ & 0.21 & 0.51 & 0.50 & 0.39 & 0.53 & 0.63 & 0.80 & 0.81 & 0.80 & 0.62 & 0.62 & 0.62 & 0.58 & 0.21 & 0.81 & 0.18 \\
\hline & SDTE & 0.45 & \begin{tabular}{|l|l|}
0.40 \\
\end{tabular} & 0.45 & 0.36 & 0.39 & 0.43 & 0.51 & 0.57 & \begin{tabular}{|l|l|}
0.64 \\
\end{tabular} & \begin{tabular}{|l|}
0.67 \\
\end{tabular} & \begin{tabular}{|l|}
0.67 \\
\end{tabular} & 0.45 & 0.50 & $\mathbf{0 . 3 6}$ & \begin{tabular}{|l|}
0.67 \\
\end{tabular} & 0.11 \\
\hline
\end{tabular}

Source: own study based on Eurostat [https://ec.europa.eu/Eurostat], access: 05.04.2020. 
The average value of the indicator of sustainable development of transport enterprises (SDTE) in the CEECs from 2008 and 2018 is in the range of 0.46-0.59. The average value of the indicator of sustainable development of transport enterprises increased in: Bulgaria by 0.26 (from 0.42 to 0.68 ), Croatia by 0.19 (from 0.39 to 0.58 ), Czechia by 0.28 (from 0.42 to 0.70 ), Estonia by 0.49 (from 0.33 to 0.82 ), Hungary by 0.47 (from 0.28 to 0.75 ), Latvia by 0,35 (from 0.43 to 0.78 ), Lithuania by 0.24 (from 0.38 to 0.62 ), Poland by 0.19 (from 0.45 to 0.64 ), Romania by 0.26 (from 0.41 to 0.67 ), Slovakia by 0.40 (from 0.22 to 0.62 ), Slovenia by 0.22 (from 0.45 to 0.67 ). The maximum value of the indicator of sustainable development of transport enterprises is observed in Estonia (2018: 0.82), while the minimum value in Latvia (2010: 0.22) and Slovakia (2008: 0.22).

In all countries of Central and Eastern Europe, the indicator of sustainable development of transport enterprises presents a positive trend. The highest factor before the variable time (t) occurs in Hungary $(\propto 1=0,0548)$ (Fig.4).

\begin{tabular}{|c|c|}
\hline 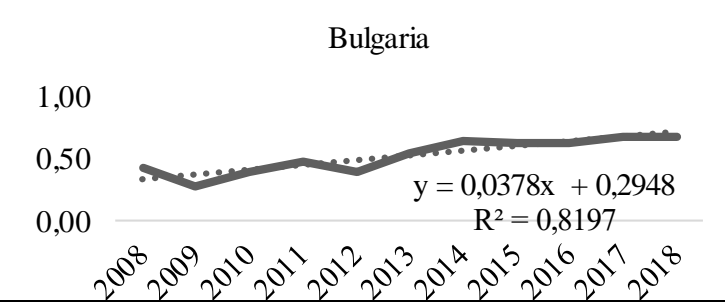 & $\begin{array}{c}0,80 \\
0,60 \\
0,40 \\
0,20 \\
0,00\end{array}$ \\
\hline $\begin{array}{l}0,80 \\
0,60 \\
0,40 \\
0,00\end{array} \quad \ldots$ & 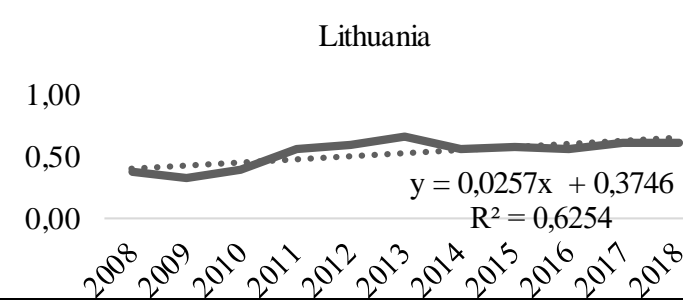 \\
\hline 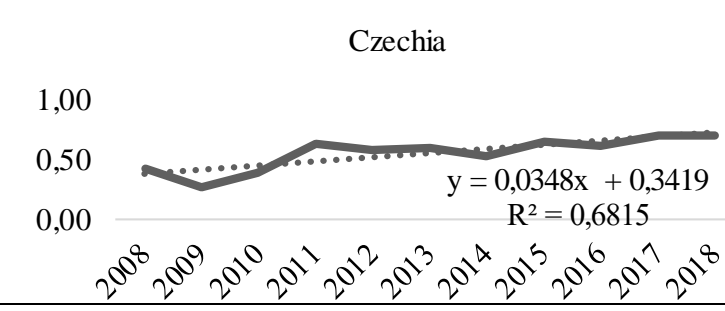 & 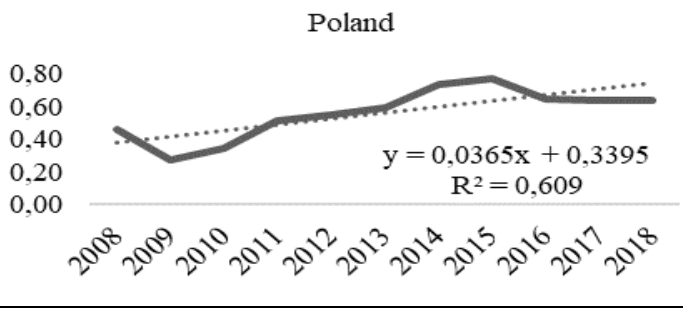 \\
\hline 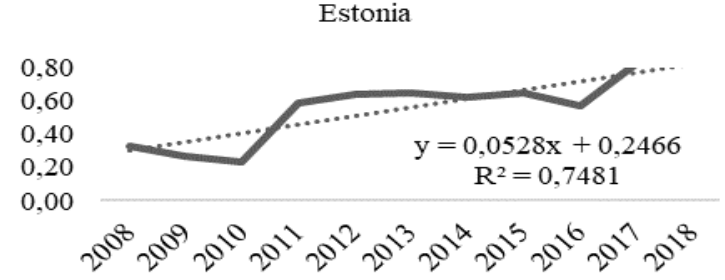 & 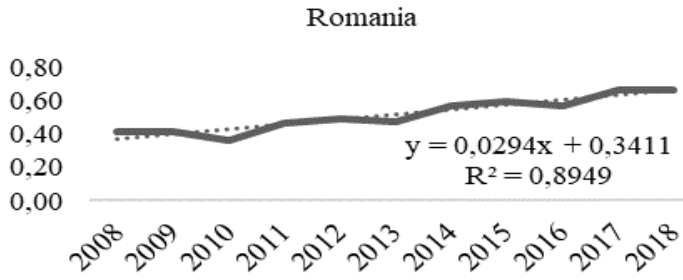 \\
\hline
\end{tabular}




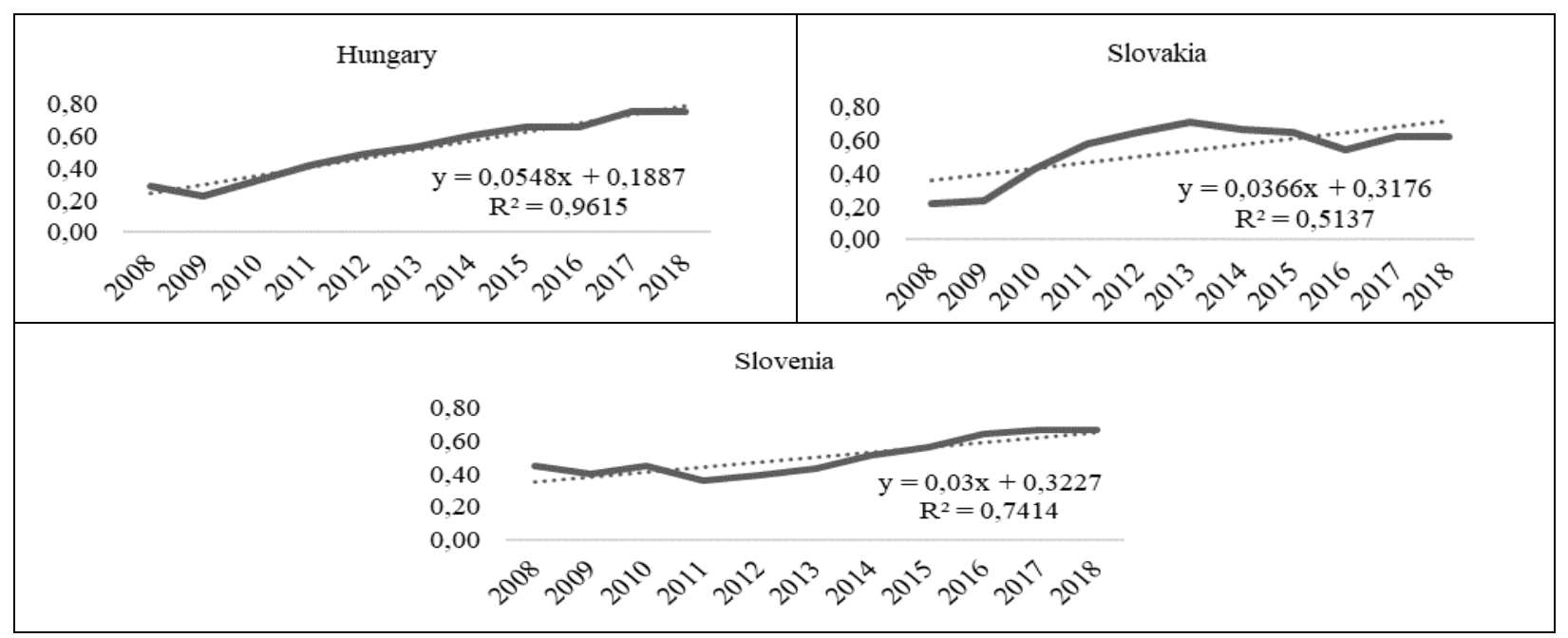

Fig. 4. Trend line for the indicator of sustainable development of transport enterprises in Central and Eastern European countries (in the period from 2008 to 2018): $\mathrm{y}=\propto_{0}+\propto_{1} t$

Source: own study based on Eurostat [https://ec.europa.eu/Eurostat], access: 05.04.2020.

The average value of the indicator of macroeconomics condition in the CEECs in the period between 2008 and 2018 is in the range of $0.51-0.59$. The average value of the indicator of macroeconomics condition increased in: Bulgaria by 0.58 (from 0.21 to 0.79 ), Croatia by 0.22 (from 0.47 to 0.69 ), Czechia by 0.45 (from 0.33 to 0.78 ), Estonia by 0.42 (from 0.36 to 0.78 ), Hungary by 0.35 (from 0.40 to 0.75 ), Latvia by 0.31 (from 0.40 to 0.71 ), Lithuania by 0.39 (from 0.36 to 0.75 ), Poland by 0.51 (from 0.25 to 0.76 ), Romania by 0.43 (from 0.37 to 0.80 ), Slovakia by 0.48 (from 0.23 to 0.71 ), Slovenia by 0.34 (from 0.37 to 0.71 ). The maximum value the indicator of macroeconomics condition is observed in Romania (2017, 2018: 0.80), while the minimum value in Bulgaria (2008: 0.21) (Table 5).

Table 5. indicator of macroeconomics condition of Central and Eastern European countries (in the period from 2008 to 2018)

\begin{tabular}{|c|c|c|c|c|c|c|c|c|c|c|c|c|c|c|c|c|}
\hline \multirow{2}{*}{ Country } & \multicolumn{11}{|c|}{ Year } & \multicolumn{5}{|c|}{ Descriptive statistics } \\
\hline & 2008 & 2009 & 2010 & 2011 & 2012 & 2013 & 2014 & 2015 & 2016 & 2017 & 2018 & Median & Mean & Min & Max & SD \\
\hline Bulgaria & 0.21 & 0.37 & 0.40 & 0.46 & 0.45 & 0.48 & 0.62 & 0.70 & 0.75 & 0.79 & 0.79 & 0.48 & 0.55 & 0.21 & 0.79 & 0.18 \\
\hline Croatia & 0.47 & 0.46 & 0.47 & 0.47 & 0.40 & 0.44 & 0.43 & 0.53 & 0.63 & 0.69 & 0.69 & 0.47 & 0.52 & 0.40 & 0.69 & 0.10 \\
\hline Czechia & 0.33 & 0.30 & 0.33 & 0.45 & 0.46 & 0.46 & 0.54 & 0.64 & 0.72 & 0.78 & 0.78 & 0.46 & 0.53 & 0.30 & 0.78 & 0.17 \\
\hline Estonia & 0.36 & 0.41 & 0.39 & 0.51 & 0.56 & 0.61 & 0.65 & 0.70 & 0.74 & 0.78 & 0.78 & 0.61 & 0.59 & 0.36 & 0.78 & 0.15 \\
\hline Hungary & 0.40 & 0.26 & 0.34 & 0.47 & 0.35 & 0.49 & 0.55 & 0.66 & 0.70 & 0.75 & 0.75 & 0.49 & 0.52 & 0.26 & 0.75 & 0.17 \\
\hline Latvia & 0.40 & 0.39 & 0.42 & 0.44 & 0.51 & 0.57 & 0.65 & 0.68 & 0.66 & 0.71 & 0.71 & 0.57 & 0.56 & 0.39 & 0.71 & 0.12 \\
\hline Lithuania & 0.36 & 0.38 & 0.38 & 0.48 & 0.54 & 0.62 & 0.69 & 0.68 & 0.69 & 0.75 & 0.75 & 0.62 & 0.57 & 0.36 & 0.75 & 0.15 \\
\hline Poland & 0.25 & 0.29 & 0.37 & 0.38 & 0.43 & 0.55 & 0.62 & 0.69 & 0.72 & 0.76 & 0.76 & 0.55 & 0.53 & 0.25 & 0.76 & 0.18 \\
\hline Romania & 0.37 & 0.32 & 0.29 & 0.35 & 0.39 & 0.45 & 0.51 & 0.63 & 0.75 & 0.80 & 0.80 & 0.45 & 0.51 & 0.29 & 0.80 & 0.19 \\
\hline Slovakia & 0.23 & 0.31 & 0.37 & 0.33 & 0.50 & 0.56 & 0.61 & 0.67 & 0.70 & 0.71 & 0.71 & 0.56 & 0.52 & 0.23 & 0.71 & 0.17 \\
\hline Slovenia & 0.37 & 0.33 & 0.38 & 0.46 & 0.42 & 0.47 & 0.53 & 0.57 & 0.64 & 0.71 & 0.71 & 0.47 & 0.51 & 0.33 & 0.71 & 0.13 \\
\hline
\end{tabular}

In all countries of the CEECs, the indicator of macroeconomics condition presents a positive trend. The highest factor before the variable time $(\mathrm{t})$ occurs in Poland $\left(\propto_{1}=0,0575\right)$. Fig. 5 shows parameters for equating the trend line for the indicator of macroeconomics condition in the CEECs. 


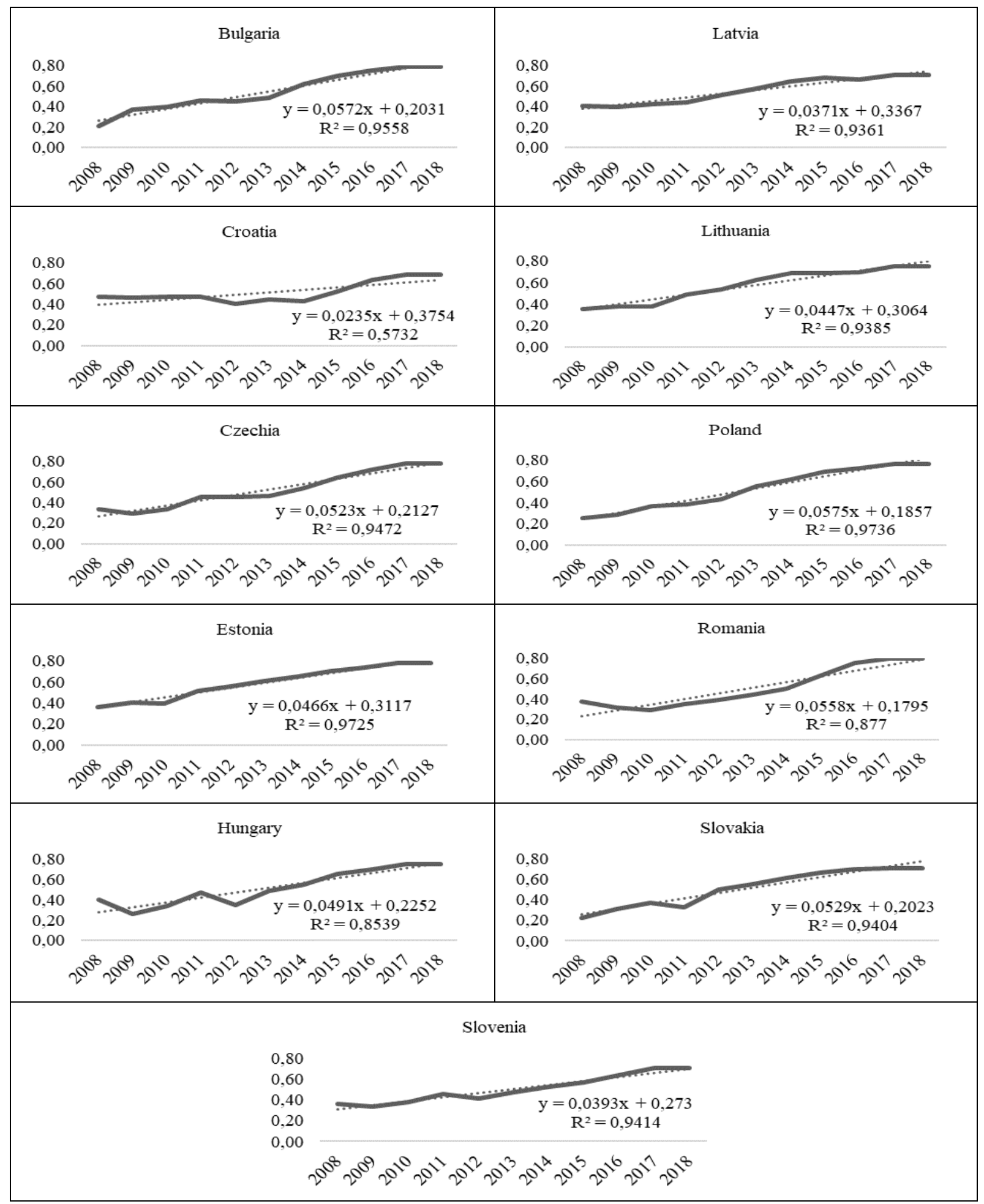

Fig. 5. The trend line for the indicator of macroeconomics condition of Central and Eastern European countries (in the period from 2008 to 2018): $y=\propto_{0}+\propto_{1} t$

Source: own study based on Eurostat [https://ec.europa.eu/Eurostat], access: 05.04.2020. 
The Pearson's Correlation Coefficient between the indicator of macroeconomics condition (Mi) and the indicator of sustainable development of transport enterprises $\left(\mathrm{SD}_{\mathrm{TE}}\right)$ is statistically significant in all analyzed countries ( $\mathrm{p}$ $<0.05$ ). The highest level of correlation is in Romania (0.94), while the lowest is in Croatia (0.59) (Fig. 6).

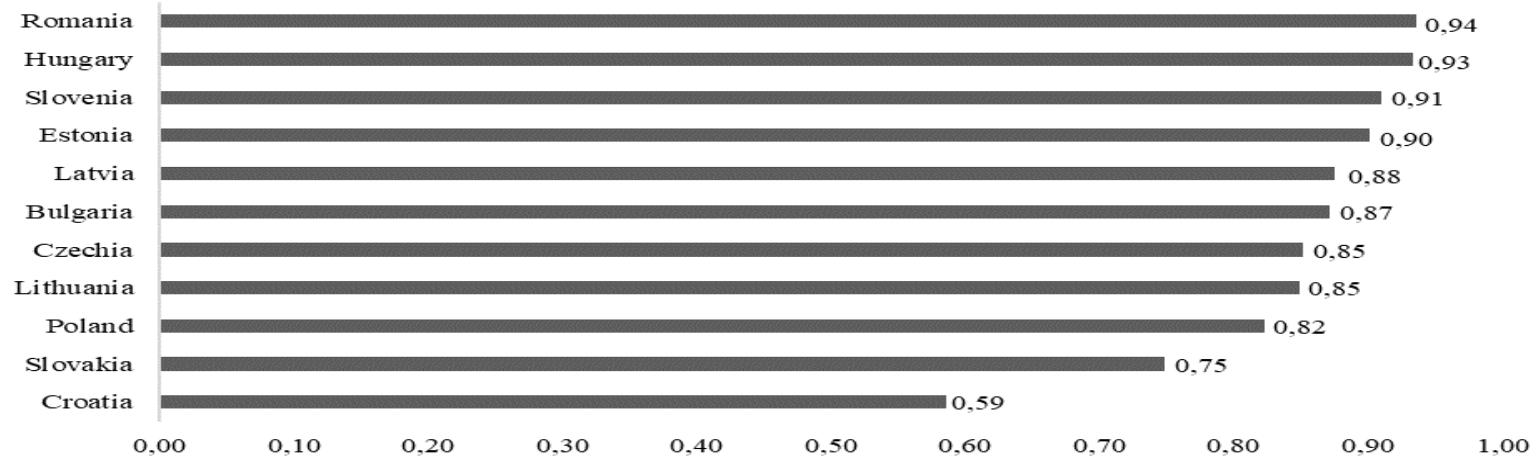

Fig. 6. The Pearson's correlation coefficient (correlations between $\mathrm{SD}_{\mathrm{TE}}$ and $\mathrm{M}_{\mathrm{i}}, \mathrm{p}<, 05$ ) Source: own study based on Eurostat [https://ec.europa.eu/Eurostat], access: 05.04.2020.

In all countries of the CEECs, the indicator of macroeconomics condition $\left(\mathrm{M}_{\mathrm{i}}\right)$ has a positive impact on the indicator of sustainable development of transport enterprises ( $\mathrm{SD}_{\mathrm{TE}}$ ), and a significant relationship between the variables studied. (Table 6).

Table 6. Results of OLS regressions: Dependent variable (SD $\mathrm{SE}_{\text {) }}$ 2008-2018: $S D_{T E}=\propto_{0}+\propto_{1} M_{i}+\varepsilon_{i}$

\begin{tabular}{|c|c|c|c|c|c|}
\hline Dependent variable & OLS & Coefficient & SD & P-value & $\mathbf{R}^{2}$ \\
\hline \multirow{2}{*}{ Bulgaria } & constant & 0.182 & 0.067 & $0.0243 * *$ & \multirow{2}{*}{0.760} \\
\hline & $\mathbf{M}_{\mathbf{i}}$ & 0.623 & 0.117 & $0.0005 * * *$ & \\
\hline \multirow{2}{*}{ Croatia } & constant & -0.005 & 0.217 & 0.9839 & \multirow{2}{*}{0.343} \\
\hline & $\mathbf{M}_{\mathbf{i}}$ & 0.895 & 0.413 & $0.0582 *$ & \\
\hline \multirow{2}{*}{ Czechia } & constant & 0.199 & 0.076 & $0.0278 * *$ & \multirow{2}{*}{0.725} \\
\hline & $\mathbf{M}_{\mathbf{i}}$ & 0.668 & 0.137 & $0.0009 * * *$ & \\
\hline \multirow{2}{*}{ Estonia } & constant & -0.125 & 0.114 & 0.2998 & \multirow{2}{*}{0.812} \\
\hline & $\mathbf{M}_{\mathbf{i}}$ & 1.164 & 0.186 & $0.0002 * * *$ & \\
\hline \multirow{2}{*}{ Hungary } & constant & 0.008 & 0.069 & 0.915 & \multirow{2}{*}{0.870} \\
\hline & $\mathbf{M}_{\mathbf{i}}$ & 0.981 & 0.126 & $<0.0001 * * *$ & \\
\hline \multirow{2}{*}{ Latvia } & constant & -0.184 & 0.147 & 0.2418 & \multirow{2}{*}{0.766} \\
\hline & $\mathbf{M}_{\mathbf{i}}$ & 1.388 & 0.256 & $0.0004 * * *$ & \\
\hline \multirow{2}{*}{ Lithuania } & constant & 0.185 & 0.074 & $0.0331 * *$ & \multirow{2}{*}{0.720} \\
\hline & $\mathbf{M}_{\mathbf{i}}$ & 0.598 & 0.124 & $0.001 * * *$ & \\
\hline \multirow{2}{*}{ Poland } & constant & 0.208 & 0.086 & $0.0377 * *$ & \multirow{2}{*}{0.677} \\
\hline & $\mathbf{M}_{\mathbf{i}}$ & 0.660 & 0.152 & $0.0019 * * *$ & \\
\hline \multirow{2}{*}{ Romania } & constant & 0.266 & 0.034 & $<0.0001 * * *$ & \multirow{2}{*}{0.875} \\
\hline & $\mathbf{M}_{\mathbf{i}}$ & 0.489 & 0.062 & $<0.0001 * * *$ & \\
\hline \multirow{2}{*}{ Slovakia } & constant & 0.173 & 0.113 & 0.1623 & \multirow{2}{*}{0.560} \\
\hline & $\mathbf{M}_{\mathbf{i}}$ & 0.702 & 0.207 & $0.008 * * *$ & \\
\hline \multirow{2}{*}{ Slovenia } & constant & 0.104 & 0.062 & 0.1281 & \multirow{2}{*}{0.828} \\
\hline & $\mathbf{M}_{\mathbf{i}}$ & 0.783 & 0.119 & $0.0001 * * *$ & \\
\hline
\end{tabular}

Source: own study based on Eurostat [https://ec.europa.eu/Eurostat], access: 05.04.2020. 


\section{ENTREPRENEURSHIP AND SUSTAINABILITY ISSUES}

ISSN 2345-0282 (online) http://jssidoi.org/jesi/

2021 Volume 8 Number 3 (March)

http://doi.org/10.9770/jesi.2021.8.3(13)

The research result allows for adopting the central research hypothesis $(\mathrm{H})$ presented in the introduction because "Macroeconomic conditions have a statistically significant impact on the sustainable development of transport enterprises in Central and Eastern Europe in the period from 2008 to 2018". In all countries, this relationship shows a high level of statistical significance. The indicator of macroeconomics condition's highest impact on the indicator of sustainable development of transport enterprises is in Latvia (1.388). In contrast, the lowest impact of the indicator of macroeconomics condition on the indicator of sustainable development of transport enterprises is in Romania (0.489). The coefficient of determination (R2) is in the range from 0.343 (the relationship between the indicator of macroeconomics conditions and the indicator of sustainable development of transport enterprises in Croatia) to 0.875 (the relationship between macroeconomics condition and the indicator of sustainable development of transport enterprises in Romania).

The high level of the analyzed dependence indicates that the state authorities should undertake actions supporting the country's socio-economic development. It is important to take initiatives and actions to support entrepreneurship and environmental protection. Financial and substantive programs of the European Union focused on innovations, new technologies, and environmental programs should play a key role here.

The first sub-hypothesis $\left(\mathrm{H}_{1}\right)$ is also true, "the indicator of sustainable development of enterprises (SDTE) in the Central and Eastern European countries shows the positive dynamics in the period from 2008 to 2018". Sustainable development of transport enterprises is due to the undertaken actions and ecological initiatives, financial support programs, increased awareness of society, and consumers' quality and expectations resulting from economic conditions.

The second sub-hypothesis $\left(\mathrm{H}_{2}\right)$ is true, "the indicator of macroeconomic conditions $\left(M_{i}\right)$ in the Central and Eastern European countries shows the positive dynamics in the period from 2008 to 2018 ". The macroeconomic conditions improve due to the recovery from the crisis, the global economic boom, and consumer moods.

The third sub-hypothesis $\left(\mathrm{H}_{3}\right)$ could not be confirmed, it is not true that "The highest average value of the indicator of sustainable development of transport enterprises $\left(S D_{T E}\right)$ shows in countries with the highest average value of macroeconomic conditions (Mi)". Sustainable development is a holistic concept that depends on several factors omitted in the study, including internal and external conditions, both quantitative and qualitative.

\section{Conclusions}

The rapid development of industry has led to environmental degradation and climate change. It has become necessary to counteract the negative impact of economic activity on the natural environment. Based on socioeconomic changes and the increase of ecological awareness, the concept of sustainable development was born. The main issues focus on conserving natural resources for present and future generations by achieving economic, social, and environmental goals.

The effectiveness and efficiency of implementing the concept of sustainable development require the commitment of all actors of socio-economic life, including enterprises, organizations, institutions, and individual countries. Sustainable development of the enterprise means improving the financial and property situation, taking care of the work conditions and the health of employees, and implementing activities to protect the natural environment.

The implementation of sustainable development goals depends significantly on the level of socio-economic development of countries. In enterprises, apart from macroeconomic conditions, the type, size, scale of operations, and management awareness are also necessary. 


\section{ENTREPRENEURSHIP AND SUSTAINABILITY ISSUES}

ISSN 2345-0282 (online) http://jssidoi.org/jesi/

2021 Volume 8 Number 3 (March)

http://doi.org/10.9770/jesi.2021.8.3(13)

In this paper, we assume that macroeconomic determinants' impact on the sustainable development of transport enterprises in Central and Eastern Europe Countries in the period from 2008 to 2018. We analyzed the transport enterprise sector due to its negative impact on the natural environment and their role in analyzing countries' economies with a similar geographical location, a shared history, and a similar level of socio-economic development. The transformation of business conditions after joining the European Union is also crucial. The research period's definition is associated with the accession of Bulgaria and Romania in 2007 to the EU and the appearance of symptoms of an economic slowdown.

We adopted the assumption, based on research conducted so far, that socio-economic development is fundamental for enterprises' sustainable development in developing countries. To verify the research hypothesis (Macroeconomic conditions have a statistically significant impact on the sustainable development of transport enterprises in Central and Eastern Europe in the period from 2008 to 2018), we create indicators of sustainable development of transport enterprises and indicators of macroeconomic conditions and examine the relationships between them (we use the Pearson Correlation Coefficient and Ordinary Least Squares Method).

The results of the research show that the central hypothesis $(\mathrm{H})$ is correct. In all countries of the CEECs, it is a positive impact of macroeconomic conditions on the sustainable development of transport enterprises. The highest degree of Pearson's Correlation Coefficient between macroeconomic conditions and sustainable development of enterprises occurs in Romania (0.94), Hungary (0.93), and Slovenia $(0,91)$, while the lowest in Croatia (0.59). The estimation of model parameters using the OLS method also indicates a statistically significant relationship between variables. The highest impact is in Latvia (1.388), the lowest in Romania (0.489).

The first sub-hypothesis (H1), "the indicator of sustainable development of enterprises (SDTE) in the Central and Eastern European countries shows the positive dynamics in the period from 2008 to 2018 " is correct. It is a positive phenomenon resulting from the increased environmental awareness of society and the good economic situation and financial programs supporting the natural environment's protection.

The second sub-hypothesis (H2), "the indicator of macroeconomic conditions (Mi) in the Central and Eastern European countries shows the positive dynamics in the period from 2008 to 2018 " is correct. The main factors here are the slow recovery from the economic crisis and the good economic situation.

The third sub-hypothesis (H3) it is not true that "The highest average value of the indicator of sustainable development of transport enterprises (SDTE) shows in countries with the highest average value of macroeconomic conditions (Mi)". Sustainable development is a holistic concept that depends on several factors omitted in the study, including internal and external conditions, both quantitative and qualitative.

Determinants of sustainable development of enterprises are exciting and complex research issues. Several factors, including macroeconomic conditions, determine them. The more economically and socially developed countries are, the more significant pressure on enterprises to comply with environmental protection and social issues. Therefore, it seems crucial to create favorable conditions for doing business in harmony with nature. From that point of view, financial and institutional support from international institutions and social pressure to take ecological actions are necessary for enterprises' sustainable development, especially in developing countries. Further research will be conducted to assess the impact of internal and external conditions on enterprises' sustainable development in the European Union 


\section{ENTREPRENEURSHIP AND SUSTAINABILITY ISSUES}

ISSN 2345-0282 (online) http://jssidoi.org/jesi/

2021 Volume 8 Number 3 (March)

http://doi.org/10.9770/jesi.2021.8.3(13)

\section{References}

Abdi, Y.; Li, X.; Càmara-Turull, X. 2020. Impact of Sustainability on Firm Value and Financial Performance in the Air Transport Industry. Sustainability, 12, 9957. https://doi.org/10.3390/su12239957

Ali, N.; Javid, M. A.; Hussain, S. A.; \& Abdullah, M. 2020. Key Performance Indicators for Sustainable Freight Transport and Scenariobased Impediments in Pakistan Freight Industry. IPTEK Journal of Proceedings Series, (5), 1-8.

Andersson, P.; \& Forslund, H. 2018. Developing an indicator framework for measuring sustainable logistics innovation in retail. Measuring Business Excellence, 22(1): 1-13. https://doi.org/10.1108/MBE-04-2017-0017

Andryashina, N.S., Garina, E.P., Garin, A.P., Seitova, Z.B., Seitov, B.M. 2020. Features of Sustainable Enterprise Development. In: Popkova E., Sergi B. (eds) Scientific and Technical Revolution: Yesterday, Today and Tomorrow. ISC 2019. Lecture Notes in Networks and Systems, vol 129. Springer, Cham. https://doi.org/10.1007/978-3-030-47945-9_144.

Arvidsson, N.; Woxenius, J.; \& Lammgård, C. 2013. Review of Road Hauliers' Measures for Increasing Transport Efficiency and Sustainability in Urban Freight Distribution. Transport Reviews, 33(1): 107-127. https://doi.org/10.1080/01441647.2013.763866

Barbosa, G.S.; Drach, P.R.; \& Corbella, O.D.A. 2014. Conceptual Review of the Terms Sustainable Development and Sustainability. International Journal of Social Sciences, 3(2): 1-15.

Bask, A.; Rajahonka, M.; Laari, S.; Solakivi, T.; Töyli, J.; \& Ojala, L. 2018. Environmental sustainability in shipper-LSP relationships. Journal of Cleaner Production, 172: 2986-2998. https://doi.org/10.1016/j.jclepro.2017.11.112

Behrends, S.; Lindholm, M.; \& Woxenius, J. 2008. The Impact of Urban Freight Transport: A Definition of Sustainability from an Actor's Perspective. Transportation Planning and Technology, 31(6): 693-713. https://doi.org/10.1080/03081060802493247

Blewitt, J. 2008. Understanding sustainable development. London: Earthscan.

Boudreau, J.; \& Ramstad, P. 2005. Talentship, talent segmentation, and sustainability: A new HR decision science paradigm for a new strategy definition. Human Resource Management, 44(2): 129-136. https://doi.org/10.1002/hrm.20054

Bowen, H. R. 1953. Social Responsibilities of the Businessman. New York, NY: Harper.

Castillo, H.; \& Pitfield, D.E. 2010. ELASTIC-A methodological framework for identifying and selecting sustainable transport indicators. Transportation Research, PartD, 15: 179-188.

Ciegis, R.; \& Zeleniute, R. 2008. Ekonomikos plètra darnaus vystymosi aspektu (Economic development in terms of sustainable development). Taikomoji ekonomika: sisteminiai tyrimai, 2(1): 37-54.

Crals, E.; \& Vereeck, L. 2004. Sustainable Entrepreneurship in SMEs: Theory and Practice. Conference proceedings in $3^{\text {rd }}$ Global Conference on Environmental Justice and Global Citizenship, February 12-14, Copenhagen, Denmark.

Davis, K. 1960. Can business afford to ignore social responsibilities? California Management Review, 2(3): 70-76. https://doi.org/10.2307/41166246

Del Giudice, A.; Rigamonti, S. 2020. Does Audit Improve the Quality of ESG Scores? Evidence from Corporate Misconduct. Sustainability, 12, 5670. https://doi.org/10.3390/su12145670

Drljača, M. 2012. Koncept održivograzvoja i sustavupravljanja (The concept of sustainable development and governance). Međunarodni skup Nedeljakvaliteta, Kvalitet i izvrsnost, 1(1-2): 1-15.

Duerr, W. A. 1975. The Role of Faith in Forest Resource Management, in: Rumsey, F., Duerr, W. A. (Eds.), Social Science in Forestry. A Book of Reading, W. B. Saunders, Philadelphia.

Dvořáková, L.; \& Zborková, J. 2014. Integration of Sustainable Development at Enterprise Level. Procedia Engineering, 69: 686-695. 


\section{ENTREPRENEURSHIP AND SUSTAINABILITY ISSUES}

ISSN 2345-0282 (online) http://jssidoi.org/jesi/

2021 Volume 8 Number 3 (March)

http://doi.org/10.9770/jesi.2021.8.3(13)

Dziekański, P. 2014. Diversification Indicator For Evaluating The Financial Capacity Of Local Government. The Case of Polish Voivodeships. Acta Universitatis Agriculturae Et Silviculturae Mendelianae Brunensis, 65(2): 611-619. https://pdfs.semanticscholar.org/2df2/a632aa0ec07f2a191b353475e12186da9fcf.pdf

Freund, R.J.; Wilson W.J.; \& Sa P. 2006. Regression Analysis. Statistical Modeling of a Response Variable, Burlington, MA: Academic Press Elsevier Inc.

Fried, T.; Tun, T.H.; Klopp, J.M.; \& Welle, B. 2020. Measuring the Sustainable Development Goal (SDG) Transport Target and Accessibility of Nairobi's Matatus. Transportation Research Record, 2674(5): 196-207. https://doi.org/10.1177/0361198120914620

Friedman, M. 1970. The social responsibility of business is to increase its profits. The New York Times Magazine, September 13.

Gagnon, M.A. 2012. Sustainable Minded Entrepreneurs: Developing and Testing a Value-based Framework. Journal of Strategic Innovation and Sustainability, 8(1), 9-25.

Gatto, M. 1995. Sustainability: Is it a Well Defined Concept? Ecological Applications, 5(4), 1181-83.

Gonzalez-Cabezas, D.; Zaror, C.; \& Herrera, M. Á. 2018. Comparative assessment of sustainable development in South American countries based onthe Sustainable Society Index. International Journal of Sustainable Development \& World Ecology, 1: 90-98.

Grabara, J.; Bajdro, P.; \& Mihaescu, L. 2015. Steps of sustainable development implementation into enterprise activities. Management of Sustainable Development, 7(1), 45-49.

Grober, U. 2007. Deep roots: A conceptual history of 'sustainable development' (Nachhaltigkeit), Discussion Papers, Presidential Department, P 2007-002, WZB Berlin Social Science Center.

Grudzewski, W.M.; Hejduk, I.K.; Sankowska, A.; \& Wańtuchowicz, M. 2010. Sustainability w biznesie czyli przedsiębiorstwo przyszłości, zmiany paradygmatów $i$ koncepcji zarządzania (Sustainability in business, i.e. the enterprise of the future, changes in paradigms and management concepts). Warszawa: Wydawnictwo Poltext.

Gudmundsson, H. 2004. Sustainable transport and performance indicators. Issues in Environmental Science and Technology, $20: 35-63$.

Hedstrom, G.; Poltorzycki, S.; \& Stroh, P. 1998. Sustainable Development: The Next Generation of Busines Opportunity. Prism, Fourth Quarter.

International Institute for Sustainable Development (IISD); Deloitte \& Touche; \& World Business Council for International Union for Conservation of Nature and Natural Resources. 1992. Business strategy for sustainable development: leadership and accountability for the '90s. IISD: Winnipeg, MB, Canada.

International Union for Conservation of Nature and Natural Resources (ed.). 1980. World Conservation Strategy: Living Resource Conservation for Sustainable Development. IUCN-UNEP-WWF.

Joshi, S.; \& Li, Y. 2016. What Is Corporate Sustainability and How Do Firms Practice It? A Management Accounting Research Perspective. Journal of Management Accounting Research, 28(2): 1-11.

Kochov, A., Danev D., \& Kostikj A. 2020. Sustainable Transport Indicators in the Context of Introducing of Electric Passenger Cars. Tehnički glasnik, 14(3): 318-324.

Lawal, F.A.; Worlu, R.E.; \& Ayoade, O.E. 2016. Critical Success Factors for Sustainable Entrepreneurship in SMEs: Nigerian Perspective. Mediterranean Journal of Social Sciences MISER Publishing, 7(3): 338-346.

Litman, T. 2009. Sustainable transportation indicator data quality and availability. Victoria Transport Policy Institute.

Majid, I.A.; Kamaludin, M.H.; Saad, M.S.M.; \& Aziz, N.A. 2012. Sustainability-driven Entrepreneurship: The Mediating Effect of Opportunity based Management Structure on the Relationship between Entrepreneurial Orientation and Environmental Sustainability Management of SMEs: A Conceptual Framework. European Journal of Business and Management, 4(13): 148-155.

Mihai, E.: Mihai, F.-C.; \& Munteanu, A.V. 2019. Sustainability of the transport sector during the last 20 years: evidences from a panel of 35 countries. Conference Proceedings of $19^{\text {th }}$ International Multidisciplinary Scientific GeoConference on Ecology, Economics, Education and Legislation SGEM, 19(5): 687-694. 


\section{ENTREPRENEURSHIP AND SUSTAINABILITY ISSUES}

ISSN 2345-0282 (online) http://jssidoi.org/jesi/

2021 Volume 8 Number 3 (March)

http://doi.org/10.9770/jesi.2021.8.3(13)

MiIntyre, J.R.; Ivanaj, S.; \& Ivanaj, V. 2009. Multinational Enterprises and the Challenge of Sustainable Development, CheltenhamNorthampton: Edward Elgar Publishing Limited.

Misztal, A. 2019. Sustainable Development of Transport Enterprises in Poland - Statistical Assessment. Logistics and Transport, 42(2): 5764.

Misztal, A.; \& Kowalska, M. 2020. The impact of globalization on the sustainable development of enterprises - the case of Bulgaria, Croatia and Romania. Prace Naukowe Uniwersytetu Ekonomicznego we Wrocawiu, 64(3): 42-56.

Moore, N. 2019. Sustainable Development Innovation: Education, Research, and Enterprise Activities at Universities. In: Leal Filho W. (eds) Encyclopedia of Sustainability in Higher Education. Springer, Cham. https://doi.org/10.1007/978-3-030-11352-0_306

Oberhofer, P.; \& Dieplinger, M. 2014. Sustainability in the Transport and Logistics Sector: Lacking Environmental Measures. Business Strategy and the Environment, 23: 236-253.

Oberhofer, P.; \& Fürst, E. 2013. Sustainable Development in the Transport Sector: Influencing Environmental Behaviour and Performance. Business Strategy and the Environment, 22: 374-389.

Organisation for Economic Co-operation and Development. 2000. Towards Sustainable Development. Indicators to measure progress, Proceedings of the OECD Rome Conference, 15-17 December.

Oželiene, D. 2017, A review of enterprise sustainable development models: critical appraisal, scientific proceedings, International Scientific Conference "High technologies. Business. Society”, 2: 257-263.

Paehlke, R. 2005. Sustainability as a Bridging Concept. Conservation Biology, 19(1),: 36-38.

Pieloch-Babiarz, A.; Misztal, A.; \& Kowalska, M. 2020. An impact of macroeconomic stabilization on the sustainable development of manufacturing enterprises: the case of Central and Eastern European Countries. Environment, Development and Sustainability A Multidisciplinary Approach to the Theory and Practice of Sustainable Development, 22(7): 1-30.

Porter, M. E.; \& Kramer, M. R. 2007. Strategy and Society, The Link between Competitive Advantage and Corporate Social Responsibility, Harvard Business Review, 84(12): 78-92.

Prugh, T.; \& Assadourian, E. 2003. What is sustainability, anyway? World Watch, 16(5): 10-21.

Rai, H.B.; van Lier, T.; Meers, D.; \& Macharis, C. 2018. An indicator approach to sustainable urban freight transport. Journal of Urbanism: International Research on Placemaking and Urban Sustainability, 11(1): 81-102.

Raykov, T., \& Marcoulides, G.A. 2013. Basic Statistics: An Introduction with R, Lanham, MD: Rowman \& Littlefield Publishers.

Salzmann, O.; Ionescu-Somers, A.; \& Steger, U. 2005. The Business Case for Corporate Sustainability: Literature Review and Research Options. European Management Journa,l 23(1): 27-36.

Schmidheiny, K. (2019). The Multiple Linear Regression Model, Short Guides to Microeconometrics. https://www.schmidheiny.name/teaching/ols.pdf.

Szanduła, J. 2014. Uwagi do unitaryzacji zmiennych w referencyjnym systemie granicznym. Przegląd Statystyczny, 2: 147-167.

Verga Matos, P.; Barros, V.; Miranda Sarmento, J. 2020. Does ESG Affect the Stability of Dividend Policies in Europe? Sustainability, 12, 8804.

Weidinger, C. 2014. Business Success through Sustainability. Sustainable Entrepreneurship, 287-301.

White, K.; Habib, R.; \& Hardisty, D.J. 2019. How to SHIFT Consumer Behaviors to be More Sustainable: A Literature Review and Guiding Framework. Journal of Marketing, 83(3): 22-49. https://doi.org/10.1177/0022242919825649

Wilcox, R.R. 2009. Basic Statistics: Understanding Conventional Methods and Modern Insights, Oxford: Oxford University Press. 


\section{ENTREPRENEURSHIP AND SUSTAINABILITY ISSUES}

ISSN 2345-0282 (online) http://jssidoi.org/jesi/

2021 Volume 8 Number 3 (March)

http://doi.org/10.9770/jesi.2021.8.3(13)

Winter, S. 2020. Wayfinding and navigation research for sustainable transport. Journal of Spatial Information Science, 20: 103-107. http://www.josis.org/index.php/josis/article/view/615/267

Witkowski, K. 2010. The aspect of integrated logistics for sustainable development. Proceedings of the Joint International IGIP-SEFI: Annual Conference 2010, Trnava, Slovakia.

World Commission on Environment and Development. 1987. Report of the World Commission On Environment and Development: our common feature.

Yan, X.; \& Su, X. 2009. Linear Regression Analysis: Theory And Computing, World Scientific Publishing.

Michal COMPOREK PhD, Faculty of Economis and Sociology, University of Lodz. Research interests: shaping the financial result in the enterprise, measurement of enterprise economic efficiency, enterprise fixed and current assets management, marketing of logistics services, economic aspects of the tourist and recreational services market, financial standing of sports enterprises.

ORCID ID: $\underline{\text { https://orcid.org/0000-0002-1402-2505 }}$

Magdalena KOWALSKA MA, Faculty of Economis and Sociology, University of Lodz. Research interests: economic and financial analysis of the enterprise, sustainable development of enterprises, operation and development of companies in the TSL sector, innovations in logistics.

ORCID ID: $\underline{\text { https://orcid.org/0000-0002-5821-0305 }}$

Anna MISZTAL PhD, Faculty of Economis and Sociology, University of Lodz. Research interests: sustainable development of enterprises and its determinants, financial and management accounting, corporate finance management, models and strategies for enterprise development, ICT in business.

ORCID ID: https://orcid.org/0000-0002-7455-5290

Make your research more visible, join the Twitter account of ENTREPRENEURSHIP AND SUSTAINABILITY ISSUES: @Entrepr69728810

Copyright (C) 2021 by author(s) and VsI Entrepreneurship and Sustainability Center

This work is licensed under the Creative Commons Attribution International License (CC BY).

http://creativecommons.org/licenses/by/4.0/

(c) (†) Open Access 